\title{
"Public Relations Work in the Diplomatic Corps" Case Study the Palestinian Ministry of Foreign Affairs
}

\author{
Ibrahim T.I. Ukka* Miraida Priscilla Bruzual Marmo Shariful Islam \\ School of Journalism and information Communication, Huazhong University of Science and Technology, \\ Wuhan, China
}

\begin{abstract}
One of the main conditions of any concept, whatever the work or level and area of clarity, integration, interpretation, compatibility, and comprehensiveness, and these leads to easy to infer the nature of work and methods, so the study seeks to identify the work of public relations in the diplomatic service in particular, the question of the problem was formulated as follows: "What distinguishes the work of public relations in the diplomatic corps from the work of public relations in general? The importance of the study is demonstrated by its efforts to bridge the research gap, which provides research, books and articles that clearly distinguish between the work of public relations in general and the work of public relations in the diplomatic service in particular, with the aim of creating a complete and complete identity of public relations in the diplomatic corps through the clarification of all aspects from the diplomatic personality to the end of the work assigned to do, and the study to give value to the existence of public relations in the diplomatic service, and the existence of basic functions are the key to international relations, In addition to the emphasis on the findings of a researcher Walid Khalaf Allah Mohammed Diab in his research "The role of public relations in the diplomatic sector," the research team based on the descriptive and analytical approach to reach the results that they want through a comprehensive description of the problem of the study, analysis of previous studies and books scientific references adopted by the research team in the study, where the research team using workers in the Palestinian Ministry of Foreign Affairs as a sample to study, and to consider working in the Palestinian Ministry of Foreign Affairs equally functionally to the public relations Department in other institutions, the study sample, and the Team to conduct interviews with a sample of the research and the relevant authorities of the subject of study doctors specialized political science Palestinians and Ambassadors, so the team can get the results that is going to get her.At the end of the research, several results were reached, the most important of which was the absence of a complete agreed definition of public relations among ministry employees and consequentially the absence of a full-integrated public relations department followed by its own units. There is also public relations as a unit of the Protocol Department, Social communication, and lack of understanding of the modern concept of political marketing.
\end{abstract}

Keywords: public relations, Diplomatic sector, Ministry of Foreign Affairs, International public Relations, Palestine

DOI: $10.7176 / \mathrm{NMMC} / 80-04$

Publication date:May $31^{\text {st }} 2019$

\section{Search terms}

Public Relations - International Public Relations - Diplomacy - Media - Diplomatic Media - Marketing - Political Marketing - Crises - Public Opinion - Contact - Political Contact

\section{Introduction}

The discrepancy between one term and two completely separate work needs to be studied in depth, to show the difference between the work of public relations in general and the work of public relations in the diplomatic sector in particular is necessary and important for the workers in the two fields, especially in light of the different needs and objectives of each area, Especially the diplomatic sector, because of its great importance in building and strengthening the image of the State in the external community and the international community, in order to gain support for the State, whether internally or externally. Public relations differ from public relations in the diplomatic sector, several aspects of, Maintaining the security, safety and stability of cities and states old was dependent on maintaining the safety of citizens and the maintenance of internal security and self-sufficiency of the state itself, but now there are developments in all aspects of life, advanced countries more than and other other where resources unlike other countries, and the presence of many countries there, including conflict, regardless of the quality of the conflict and most border conflict, so the view of the above showed the urgent need for the existence between countries to ensure the needs of each other and help others have relationships.

Inter-State cooperation and communication must be characterized by the nature of peaceful, peaceful diplomacy, free from fighting and wars through peaceful negotiations based on the art of persuasion far from war. Thus, the role of the state is manifested in the establishment of units, bodies and personalities representing these processes of communication and cooperation through the adoption of policies Reducing the negativity and conflict between them and reaching agreement on their international relations And at the same time working to 
increase the strength of the cohesion of relations, especially the cooperative of all kinds.

The impact of international relations is not that of one individual, but of all the people. Hence, the sensitivity of international relations is reflected in rules, protocols and protocols, especially when communicating and cooperating with other States.

The impact of these international relations shows the strength of public opinion, which is considered to have a significant impact, especially now, in the light of technological developments that enable all individuals to express their opinions and create a great revolution by entering the world of technology, social media and the new media, Political support, so support public opinion of the policy of the State, whether domestic or foreign policy is a strong factor in the success and realization of that policy.

The role of public relations as efforts and attempts to create these strong relations in the consolidation of friendship, understanding and mutual respect between the State and other countries and public relations to achieve cooperation and the convergence of cultures between countries to contribute to the development of international communication through international relations strengthens

It supports the concept of public relations and achieve its leading role, and this is therefore Positively affect the reputation of the state and achieve international communication that is more international relations, which supports and achieves the concept of public relations better

One of the functions of public relations in the diplomatic sector is to explain the objectives of the political, economic and social system prevailing in the country, and therefore this requires qualities and characteristics enjoyed by the diplomat working in international relations.

Diplomacy is to have that intelligent person who is tactful, politicized, negotiating, persuasive and conversational in the ability to deal with other people with the full knowledge and knowledge he has about him. It shows the important role of the diplomatic person in consolidating the relationship between his country and the recipient country, confidence, and this depends on those qualities that must be enjoyed, the credibility of the information in his possession and precision used by the preselected topics and put forward, and calm in the deal, which must be away from the attack and defend the barbaric trait that leads to corruption relations and Mint $\mathrm{O}$ war and corruption relations, and this was confirmed by Dr. Hanna Issa in an article published on "diplomatic and personal advantages (Issa, 206)

As the media broke into all areas of life, there was the so-called diplomatic diplomatic media. After the development of the media and its means, there are no longer so-called supreme secrets or special files that are not revealed. Rather, the requirements of the development and prosperity of the state are that the people have the know-how and science The state, except for files and matters affecting the security of the state and its stability, came to the media and especially the political to broadcast and show all the views and directions of the decision makers and senior politicians in countries, except that the diplomacy is considered as an information system tasked to transfer the internal image of the state and its conditions to the outside world $\mathrm{J}$, and it is a communication channel shows the positions of the state .

Based on the above, the research team conducted a study entitled "The work of public relations in the diplomatic corps" and the selection of the Palestinian Ministry of Foreign Affairs as a model "and follow the descriptive analytical approach, considering the employees of the Palestinian Ministry of Foreign Affairs are the study society, while the employees of the Palestinian Ministry of Foreign Affairs To the public relations department in other institutions sample study, and to achieve what is desirable from the study and answer the question of the study, "What distinguishes the work of public relations in the diplomatic corps for the work of public relations in general? The research team has retrieved two study tools: personal interviews through the intended sample, and the use of the observation form. The importance of the study is based on the consideration of international public relations work through the tool of peaceful diplomatic diplomacy, that is, by persuasion and negotiation, This was confirmed by Dr. Hanna Issa in an article entitled "International Relations and Diplomacy (- Issa, 2016).and in support of that public relations and public diplomacy are two sides of the same coin as D.khalaf God said in his study" The role of public relations in the diplomatic sector (Khalaf Allah, 2010)

In addition, international public relations have become particularly important in light of the technological, political and economic changes taking place now. The study also draws on the importance of providing information and data on the organizational, administrative, communication and media aspects used by public relations employees in the diplomatic sector. identify the nature of the performance of this function and the study of crises that are exposed methods and response, in addition to knowing the extent that iswhere the use of modern communication technology and the impact on the work, knowledge of the qualities and skills that must $\mathrm{N}$ is characterized by the status of the communication of public relations in the diplomatic sector

The study contributed to increasing the knowledge of the role of the factor in the public relations in the diplomatic sector. This came after many studies that talk about international and diplomatic relations, but they do not expand on that and look for the powers and the main tasks and how to implement them, especially the political crises and how to confront them. The reason for this study is that it seeks to bridge the gap in research gaps that provide a clear contradiction between the work of public relations in general and the work of public 
relations in the diplomatic corps in particular, with the aim of creating a complete and complete identity of public relations in the diplomatic corps. The study aims at giving value to the existence of public relations in the diplomatic corps and the existence of key functions that are the key to international relations, in addition to emphasizing the results reached by researcher Walid Khalafah Mohammed Diab in the research (E) The role of public relations in the diplomatic sector (Khalaf Allah, 2010)The study worked to achieve what was recommended by the researcher Walid Khalaf Allah in his research mentioned nose, and help the study to facilitate the work of students and researchers to access references that clearly identify differences,

And use the study as a starting point when conducting other research related to public relations in general or public relations in the diplomatic service in particular.

The study contributed to the increasing role of the media in the diplomatic field as an essential tool for diplomatic work, and the need to use these means to convey views .

At the end of the study, several results emerged, the most important of which was the lack of a complete agreed definition of public relations among ministry employees and consequently the absence of a full integrated public relations department followed by its own units. There is also public relations as a unit of the Protocol Department,

Another consequence is that the State Department does not deal with social networking sites and does not recognize the modern concept of political marketing.

\subsection{Problem statement:}

The study seeks to identify the work of public relations in general and the work of public relations in the diplomatic corps in particular and thus distinguish between them, in light of the different needs and objectives of each area on the other, and the question was formulated the main problem as follows:

\section{What distinguishes the work of public relations in the diplomatic corps from the work of public relations} in general?

\subsection{Study Questions:}

1. What is the definition of public relations in the diplomatic corps in particular?

2. What do we mean by diplomatic information?

3. What is political communication and its methods?

4. What are the characteristics of the diplomatic personality and the person working in public relations and the tasks entrusted to him?

5. What is political marketing and its importance?

6. What political crises and how to deal with them?

\subsection{Objectives of the study :}

\section{The study aims to achieve the following goals:}

1- The ability to distinguish between work in the field of public relations in general and work in the field of public relations in the diplomatic service in particular.

2- Knowledge of diplomatic media and media as a unit of public relations in general.

3- Knowledge of aspects of the communication process in the diplomatic corps all.

4- The ability to know the qualities that characterize the worker in the diplomatic corps and its functions.

5- Understand the meaning of the process of marketing the diplomatic corps in particular.

6- Know the mechanism of dealing Public relations with political crises in the diplomatic corps.

\subsection{The importance of studying:}

The work of international public relations is through peaceful and secure diplomatic tool, ie, following the persuasion and negotiation skills, diplomacy is only the application of foreign policy, and this was confirmed by Dr. Hanna Issa in an article published entitled "International Relations and Diplomacy," and in support of that public relations and public diplomacy are Two sides of the same coin as said by Dr. God in his study entitled "Public relations in the diplomatic sector".

The study derives its importance from considerations and scientific matters that undoubtedly exist and apply. The most important of these is that international public relations have become particularly important in light of the technological, political and economic changes that have taken place.

The study derives its importance from the contribution of providing some information and data on the organizational, administrative, communication and information aspects used by the public relations employees in the diplomatic sector, in order to identify the nature of the performance of this function, study the crises and methods of confronting them, Limiting the use of modern communication technology and the impact on work, and knowledge of the qualities and skills that must be characterized by existing in the communication of public relations in the diplomatic sector. 
And contributed to the study to increase the knowledge of the work of working in public relations in the diplomatic sector, and came after the existence of many studies that talk about international and diplomatic relations, but they do not expand it and talk about the powers and functions key and how to implement them, in particular the crisis policy and how to address them.

\subsection{Justifications for the study:}

Sought the study to work to bridge the lack of research that provides the paradox gap and the comparison is clearly between the work of public relations in general and the work of public relations in the diplomatic corps , in particular, with the aim of creating an integrated full identity for public relations in the diplomatic corps comes by clarifying all aspects of starting personal Diplomacy to the work assigned to it, and the study was to give value to the existence of public relations in the diplomatic corps and the existence of key functions that are the key to international relations, in addition to emphasizing the findings of researcher Walid Khalafullah Mohammed Diab in his research "The role of public relations In the diplomatic sector ".

Worked the study to achieve recommended by the researcher Walid Khalaf Allah in his nose above, and helped the study to facilitate the work of students and researchers with access to references define them the ability to reach and find out differences and irony, and the comparison is clearly between the concept of public relations in the general sense and the concept and role.

Public relations diplomatic corps special sense, the use of the study is important reference when making other relevant research, both in public relations sense of general or public relations in the diplomatic corps concept special .

And contributed to the study emphasize the growing role of the media used in the diplomatic field and considered as an essential tool for the work of the diplomatic and achieve the role of public relations in the diplomatic corps, to the need to use these means in the transfer of views and this is confirmed by the researcher D.hmt Hassan Abdul Majid in his "models use the means Media in the diplomatic field ".

\subsection{The limits of the study:}

Field Limit: The team selected the offices and headquarters of the Palestinian Ministry of Foreign Affairs in Ramallah for the purpose of carrying out this research and to answer its questions.

Time Limit The study examined the public relations activity of the Ministry in the last three years, from 2015 until the first three months of 2017.

\section{8. Terminology of study:}

1. Public relations:

A) An ongoing process through which management seeks to maintain and enhance understanding and trust between its clients and the public in general through self-analysis and correction (internally) and through all modes of expression (externally) Offers public relation news Defined as an administrative function to assess public attitudes, link policies and procedures to the individual or organization with public interests, and implement a practical program for public understanding and acceptance.

B) Longman's Media and Communication Dictionary is defined as an administrative function to assess public attitudes and follows the ongoing policy and activities of the organization that are in line with the interests of the public.

C) One of the most comprehensive definitions is the definition presented by Dr. Rex Harlow, a sociologist and public relations practitioner, that public relations is a distinctive administrative function that helps to establish and maintain lines of communication and mutual cooperation between the institution and its public. It also includes the management of problems and issues and helps management to remain informed. Public opinion and response

D) Craig Aronov and Otis Paskin are known as public relations. They are an administrative function that helps define and facilitate change in the organization's goals. Public relations officers communicate with the internal and external public of the organization.

E) The definition of public relations as a function of planning was defined as an administrative function of a planned and continuous nature, through which public and private organizations and organizations seek the sympathy and support of those who care about them and maintain their trust by assessing their public opinion for their policies and procedures as much as possible. In order to achieve cooperation that is more fruitful and to meet public interests more efficiently by planning and disseminating information.

\section{Public Relations in the administration of government:}

Public relations occupy a distinguished position in the organizational structure of government institutions. The importance of this department differs from institution to institution depending on the objectives of the institution and its relationship with the public, and the nature of the services provided by the establishment of this administration of human cadres and the potential of material and powers. (Tarawneh, 2009) 


\section{International Relations:}

International relations are one of the fields of human knowledge has emerged recently, where it was produced by successive international events, so it is a wide area of study and research is sophisticated and growing and the growing and broad scope of international events, it absorbs the events and relations that intertwine among the countries of the world. That international relations are able to deal with the changes of the new era in the world as a whole, including developing countries and Arab countries in general because they found the appropriate environment for easy transition and rapid access to information and international media and rapid international exchange, and attention to global public opinion,

All these factors have made international relations and strategies an appropriate environment to be used optimally to promote the world politically, economically, intellectually and culturally so that the world can live in peace, security and security. This is the summit of the work of international relations for which it was found.. (issa, 2014)

International public relations are the link between the institutions of one civil society and other societies by providing specific services based on mutual trust

The importance of the individual and social strata, and the impact of public opinion in societies on various economic, social and political institutions (Behind Allah, 2012)

\section{Diplomacy}

Diplomacy is the process of communication and negotiation in international politics aimed at managing international relations and settling and regulating these relations through diplomatic envoys and ambassadors, a foreign policy process, as the instrument of implementation of this policy (Wadi, 2013)

Diplomacy is a set of concepts, rules and procedures and protocol and international institutions and norms governing relations between States and international organizations and representatives al diplomatic $\mathrm{n}$, with a view to the higher interests of service (security and economic) and public policies and to reconcile the interests of countries by communication and exchanges and conduct political negotiations and the holding of international agreements and treaties and is considered Diplomacy is a major tool to achieve the objectives of foreign policy to influence the countries and external groups in order to gain and gain support in various ways, including what is persuasive and moral, including what is intimidating (padded) and uncircumcised $\mathrm{J}$. In addition to communicating information For governments to promote and develop relations in various fields, to defend the interests and people of their nationals abroad, to represent governments in events and events, to collect information on the conditions of states and outside groups, and to assess the positions of governments and groups on current issues or possible reactions to policies or positions. Futuristic.

One of the important roles of diplomacy in international relations (issa, 2014).It is 1.the first instrument of implementation of the State's foreign policy.

2. The first means for decision-makers to justify their decisions and convince others within the framework of the international interaction movement.

3. Has attracted the attention of the world's media community because of its role in the conduct of international affairs.

4. The first means for States to facilitate peaceful and friendly relations between them.

5. Diplomacy is the primary instrument for that person involved in the exercise of negotiation and representation of the diplomat (diplomat) who uses it to bring the views and reconciliation of Balada and other countries closer together.

6. Used by States after their independence and realization of national sovereignty for self-assertion in the international community where diplomacy is exercised in all its manifestations, such as diplomatic representation, information, negotiation and treaty making.

7. It is a means of achieving peace in the interaction of the international community. It therefore enters the ideal school (moral-legal), which is optimistic about building a world free of conflict and conflict.

5. Media:

1. Francis Pal knew the media as an exchange of information between individuals and added to him the factor of means and equipment that make this exchange possible but did not specify the nature of these means, leaving them in general as these media outlets have become concerned with this definition is not exact, which made the school Anglo-Saxon intervene to correct the previous definition We say that these means are referred to by Francis Pal media mass Mass media means that mass media are mass media. (Ahmed, 2007)

2. Ibrahim Imam knew the media as the objective transfer of information from the sender to the future and against the conscious impact on the mind of the individual to allow him the possibility of forming an opinion on the basis of the facts presented in the sense of the media always convey the facts and this service to the owner and this within the understanding between the sender and the future and therefore the media is different from advertising. (Ahmed, 2007) 


\section{6- Political Media:}

Political media is one of the branches of the media, which is characterized by its ability to influence and change and persuasion and is interested in covering the political issues and seeks to achieve political objectives and is one of the effective tools and the main depends on which political system used in the achievement of different strategies (Prince, 2013)

Objectives of Political Media at the National Level (Prince, 2013)

1. Impact in directions.

2. Control of government.

3. Political education.

4. Political Marketing.

5. To strengthen loyalty and support between the sender and the future, and to establish a sense of allegiance to the development of a national culture.

6. Facing external propaganda, and working on consensus and behavior within society.

The objectives of only Allam political at the international level (Prince, 2013)

1. To collect adequate information about the political, social and media environment within the country and the countries to which it is intended to work or work.

2. Support foreign policies or issues of States at the international level.

3. Create images and positive impressions about the state and its institutions when recipients in other countries, and the radio stations and television channels pain point out this role normally.

4. It means studying the policies of the media from the state for a other as to each State policy Alkha 's share in the field of media and communication.

5. Achieve a kind of cultural overlap of the State or group of States contact list within the State and to support the culture of the state or the organization of a regional group representing countries.

\section{Marketing}

Marketing is defined as the process of planning and implementing the pricing, promotion and distribution of ideas, goods and services to provide an exchange that satisfies the needs of customers and achieves the objectives of organizations. Therefore, marketing is a set of functions aimed at facilitating the exchange of goods and services. (Al-Hashawi, 2012)

\section{Political Marketing}

There is no agreed definition until Alan

Arun Okas defines him as the analysis, planning, implementation and control of political and electoral programs that ensure the building of mutually beneficial relations between a political entity or a candidate and voters, and maintaining this relationship in order to achieve the goals of the political marketer. (Beauty, 2005) ${ }^{-}$ Known Buller and Farrell political marketing that the exchange process that takes place in the election period when politicians are vendors - seek to increase their profits - to market themselves, through the implementation of activities of direct promotional. (Beauty, 2005)

A third group defines political marketing based on the definition of commercial marketing as seeking to establish, maintain, expand and strengthen relations with voters in order to benefit or benefit society and political parties, by sharing benefits with others and by making political parties' promises. (Beauty, 2005)

Another definition is that political marketing is the application of the principles of marketing and its methods in the political campaigns carried out by these political entities, Parties, or Individuals, these include methods of political and market planning and implementation of political campaigns analysis. (Beauty, 2005)

According to Jennifer Marshall, political marketing is the result of a combination of marketing and politics, and in practice represents a breakthrough for political space through marketing. (Al-Anzi, 2016)

A. Political Marketing Functions: (Adel, 2012). One of the demands of the successful political marketing department, according to political marketing theory analysts, is in eight key functions:

1.Production Function_In the exercise of political marketing there is an exchange between political parties and voters in the The electoral market, each party offers some products, the promise of a rational government, and in some cases the producer may be the image of the candidate - the ideology Or specific foreign policies, so the marketing process is designed to market the product, and in the USA The primary product function of the Democratic Party is the sale Obama's political image and good governance based on change.

\section{Distribution function}

Refers to the conditions for the exchange of the exchange partner and this function has two dimensions Connect the campaign and connect the offer and the campaign delivery function will provide the exchange partner And voters by making available appropriate information on the political product, including broadcasting Information on partisan policies and programs, placing candidates in proper channels and ensuring that the distribution medium is appropriate to the ideology of the party.

3. Cost function one of the basic functions of integrative marketing is the sale of a product that is cost-effective compared to other products in the market. In political marketing, the cost function refers to the management of 
the behavioral and behavioral constraints of voters through carefully calculated campaign strategies so that the voter receives information related to the product without spending money on me. That.

\section{The function of communication}

involves communicating the function of the basic exchange partner to the offer and making it available and is often seen as the core of political marketing. For the political party political content includes political ideas and future programs

The interpretation of complex political reality, communication function often include simplifying political messages and political position.

\section{5._News management function}

The communication function is linked to the secondary exchange partners. It is the management of the candidate or party's reputation. Examples include public relations activities, the media, online advertising campaigns and all functions of news management. In the age of communication revolution, news management plays a vital role in the success of political marketing.

\section{The job of increasing funding}

the political marketing department cannot continue with the prospect of increased funding, job success others depend on degree

A significant function of increased funding, and to provide a political candidate with appropriate sources, so the political party depends on party membership fees and donations.

\section{The functionality of the parallel campaign management application}

This function describes the coordination requirement, the campaign tool, and the party's political and party activities Parallel organizations, where the use of parallel campaigns helps to increase the credibility of the political message.

\section{Internal thread management functions}

The relationship with members of the party, Activists, and speakers where you play the marketing function internal role is vital in creating internal stability and credibility of the external image of the party.

\section{Crises}

The crisis is a critical turning point in the course of an event, characterized by a marked improvement or a sharp delay, associated with old attractions that must be replaced by new links, and which will bring quantitative and qualitative changes to the event. (Al - Baldawi, 2007). Coral, but the rise of conflicts to a level threatens to change the nature of international relations between States (Al - Baldawi, 2007).

Robert North ( Robert North ) Indicates that the international crisis is a sharp escalation of action and reaction, that is, a process of division that changes the level of effectiveness among States and leads to an increase in the degree of threat and coercion . (Al - Baldawi, 2007)

\section{General opinion}

- Twins: The public opinion as a unified opinion of the group is inconceivable, because the courage of people in the struggle for its existence and lives are different so that their desire to life is not one and their goals are different (Al - Dabisi, 2012) In public opinion, public opinion is not the opinion of the entire people, but the opinion of a class that has a majority and power among the classes of other people. (Al - Dabisi, 2012)

- Yang defined it as a social judgment that expresses conscious society on a general issue of importance, and that this social provision must be reached through a general discussion based on reason and reason and that this provision should be so severe and profound that it affects public policy.

11. Connection

Definition of communication for public relations experts:

- However, communication is a two-way road and is therefore the most powerful factor that ensures that the two sides of the communication understand each other's views and work to achieve their desires, bringing them together in that common interest ${ }^{\circ}$ (Mersley, 2007)

- The process of communication means communicating the information in order to find the desired change in the behavior of others. Therefore, it is a process consisting of at least one sender and one receiver, sending information and understanding from the sender to the receiver (Mersley A. B., 2007)

- Some researchers say that the communication is broader and more comprehensive than the exchange of information in opposite directions. The means used in this communication exceed the target audience by this communication.

\section{Political Communication:}

- It is called a political connection which is all the techniques used by political actors and rulers in addition to helping the specialists in the field of political communication, such as professionals in the field of political advice to communicate with voters and sentenced and all technologies borrowed from the field of marketing such as the technique of sounding opinions, public relations and publicity as well as the use of modern technologies Such as automated media and advanced audiovisual aids such as electronic media in politics (Hashemi, 2009) 
- The total number of political messages transmitted by the rulers and politicians in general to the electorate, depending on some channels and props such as public speeches, dialogues, posters, leaflets. It is noticeable that while the first definition focuses on the practices and channels of communication communication, between rhetoric and politics while the other definition we see focuses on the content of the message contained in the political information (Casinav, 2014)

\section{II.Previous studies}

1. The Title : Political Media

Author : Youssef Abdullah Ali Hussein

Date : 2016

\section{Summary}

The writer seemed to study the definition of politics and political media, and ended the study of dialogue and political contact, has written this study based on the development of society and thus the evolution of modern political systems, and in line with the emergence of public opinion and as a force defines public policy in the society, and to regulate the relationship between the political system and public opinion does not must be a connection to regulate the relationship system, and spoke about the political media in terms of its objectives, and types, and its means, its functions and its importance, and pointed out that the political media is different from one country to another, due to the difference in the ruling political system and also differ system media in your For a state.

He concluded the writer to many of the recommendations, including the need for the media interpretation of events and political phenomena of all, and that the direct news coverage is not to become the basis for the performance of the functions of political communication, and added the political executive and national institutions need to work to develop effective communication channels with media organizations, what Ensures a rapid and adequate flow of information that is needed by the public and which is needed for ease and convenience.

He pointed out that the political system should focus on developing a communication structure that facilitates the process of information flow so that it does not lead to cognitive confusion or confusion in the currency of understanding the facts. It has been clarified how useful communication operations are in continuous follow-up with political news, where it is through the media are predicting any event possible to get and therefore it is possible to form capacity and plans prior to the face of any event possible to get, and thus helps to reduce the risk of for any sudden change is not for the benefit of the institution, so stressed the importance of giving the media authorities to act in $\mathrm{h}$ the existence of any of a Meh, the writer added that the Arab countries of its political system, which is characterized by special condition,

Which is that the Islamic law is the basis for the supreme authorities of this system, and this has been linked to the freedom of political media, and made clear the difference between free media and political information. (Youssef, 2016)

\section{Title : Diplomatic personality and its characteristics}

Author: Dr. Hanna Issa

Date: 2016

Summary

The writer began his article by defining the term "diplomacy" and what it means. He went on to the meaning of negotiation, which is considered the other side of diplomacy. If diplomacy succeeds in peace, if it does not succeed, it often opens the door to war. Negotiating representatives who are known as diplomats. The diplomat said that diplomacy is the professional method of conducting dialogue and depends on the personality of the diplomatic negotiator. He then defined the diplomatic person and the importance of choosing the right diplomat. He also noted the important role played by the diplomatic person in consolidating the relationship between his country and the recipient country. The author pointed to the qualities and attributes Necessary that must be available in the diplomatic person and duties diplomacy centered on the process of collecting all the information task that has a relationship to his country and to send it to his mother. (- Issa, 2016)

\section{Title : Theories of International Relations Specialization and Diversity " Book "} Author: Tim Dunn, Melia Corky, Steve Smith

\section{Year: 2016}

Summary

This book contains three authors efforts on the specialization of International Relations of Political Science, it included the book fifteen chapters with topics varied and many, including theories of international relations, and the field of international relations, and its relationship to social theory and the normative and the globalization of science, and included the book examples and cases of several under the name of " A case study "that helps to link theory and practice, in addition to enriching the tools and methods that help to develop 
understanding and enhance the ability to interpret international phenomena in all dimensions, and provide authors new ways to understand international relations through (Tim Dunn, 2016)

Time, space, and discuss what the late Palestinian intellectual Edward Said in his book "Orientalism" wrote. At the end of the book there was the general conclusion of the whole book on the specialty of international relations that international relations should not be treated as an end in itself, that is, the specialty of international relations must be closely related to life and at the same time we do not abandon theory because specialization without theory or Methodology is not useful in the long run and that the ideal of specialization is the relevance of society through the theory and the importance of being linked to a practical role.

\section{Title : Media and Public Diplomacy}

\section{Author: Saleh Salem Saleh}

Date: 2015

\section{Summary}

The author began by defining public diplomacy and addressing a set of definitions. The writer divided his book into eleven chapters, which he began with public diplomacy to study the concept and clarification of all aspects of theoretical diplomacy. He touched upon the Fischer model of public diplomacy and concluded the first chapter by comparing traditional public diplomacy with $21 \mathrm{st}$ - The end of the research that the future of diplomacy depends on scientific research in the development of different aspects and dimensions and build new theories along with a range of different sciences in the process of development, such as public relations.

He spoke about public diplomacy and its interrelationship between a range of concepts such as propaganda, psychological processes and public relations. In this chapter, he talks about public diplomacy and public relations and their similarities and differences, although there are similarities but they work separately and do not constitute one academic or professional community. How public relations theories contribute to the development of public diplomacy, and finally talked about the development of the science of public diplomacy as a new field of science while not forgetting the distinguished role of researchers in the field of public relations. In addition, after the events of September 11 there was a kind of integration between the relations and public diplomacy in the context of strategic communication efforts. He talked about public diplomacy and soft power, where he explained the concepts of soft power and its relationship with other sciences and public diplomacy and ended the chapter with some of the results. (Saleh, 2015)

In other chapters, concepts that conflict with public diplomacy and its relation to public opinion, strategic communication and cultural diplomacy as a basis for public diplomacy and the cultural role of embassies where embassies play an important role in cultural communication with citizens,

In the last chapter, the researcher focused on the process of building and developing national diplomatic systems. He expressed the importance and the role of the Ministry of Foreign Affairs to coordinate between the activities of the Ministry of Foreign Affairs and the Ministry of Foreign Affairs. All components of the national diplomatic system.

\section{Title : International and Diplomatic Relations \\ Author: Dr. Hanna Issa}

\section{Year: 2014}

Summary

Dr. seemed to his article by T. Master of International Relations in the language and the general concept as well, said the reason for its appearance as a science, and he learned studying the links and links between countries, and he learned includes aspects of daily life are all. He then referred to the concept of diplomacy and its other concepts of international norms, procedures, customs, ceremonies and institutions, all of which regulate the relations between States and international organizations. He then referred to diplomacy and its impact on international relations and it is the peaceful tool of the work of international relations. That the most important process in diplomacy is to negotiate. He pointed out that the study of organizational and administrative means Connection Used FromBefore management relations the public in a Sectors of diplomatic and those who communicate aims to identify On Nature performance function relations the public International And measuring the effectiveness this is means in a Investigation Objectives Required Evaluation of this performance, study of problems and obstacles and ways to address them, and extent Use Based contact in a relations General Technology Connection Modern And effect that On Work performance, knowledge of communicative qualities and skills that Must be That is available in the existing contact in the work diplomat, As well The quality of models used in communicative roles of practitioners relations the public International In embassies and diplomatic sectors. He referred to the role of diplomacy in the management of international relations and outlined the duties and duties of the diplomatic mission in international relations. (- Issa, 2016) 


\section{Title : The Role of Informal Diplomacy in Implementing Palestinian Foreign Policy Author: Dr. Abdel Hakim Soliman Wadi \\ Date: 2014 \\ Summary}

This study is considered the first of its kind in Palestine. The researcher first spoke of an ancient term that first appeared in Greece, namely diplomacy. He then moved to the definition of informal diplomacy. He emphasized that it is the informal efforts in diplomatic work. Media and non-governmental organizations.

Al-Wade stressed that the development of international relations and the fact that traditional diplomacy alone is not an effective tool for the implementation of foreign policy and the emergence of so-called modern informal diplomacy, the researcher analyzed and explained this type of parallel diplomacy and considered it a tool of foreign policy, Official diplomacy. He stressed that the activities of informal diplomacy have widened due to the so-called globalization, the spread of democracy, the protection of human rights and development events, and their popular support with the participation of parallel diplomacy alongside official diplomacy. A knowledge approach in the field of international relations, and taking Palestine as an example as an emerging state in its international relations depends mainly on diplomacy. He stressed his desire to know the effectiveness of informal diplomacy in the Palestinian model by influencing international relations and the role of non-official diplomatic actors on the domestic level and its impact on the external level.

The researcher relied on a central question, what is the role of informal diplomacy in the implementation of foreign policy objectives and priorities to achieve a rational foreign policy based on informal popular participation. Then a set of sub-questions.

In addition, adopted the formulation of a main hypothesis and the object of study or deny or prove.

In addition, use a historical approach, then descriptive approach, and a functional approach to highlight the role of informal actors in political decision-making in the field of international relations. The methodological approach and analytical legal method by analyzing a set of important positions and stations that need informal diplomatic support, Between official diplomacy on the one hand and informal on the other. (Hakim, 2014)

\section{Title: Multi-track diplomacy}

\section{Author: Mohammed al-Bukhari}

Date: 2013

Summary

The researcher focused on several areas, the first of which was the definition of international public relations (public diplomacy), the professional definition of public relations, the comprehensive social definition of public relations and the social definition of public relations. He then began to talk about public relations activities in the international governmental sphere, Governmental organizations and bodies, public relations in the European continent and the United States of America, taking some Middle Eastern countries such as Egypt and Uzbekistan, and then talking about public relations and crisis management, the public relations functions of governments and Civil society.

The researcher concluded during the research that the role of the public relations expert is limited to convincing the senior management to carry out activities that make the public satisfied with the institution, and convince them that the institution deserves support and moral and material support. And that the role of public relations is limited to the adoption of the public's interest and interest Amh.owalsaa to deliver information about the Foundation's activities and policies of Gmehor.o he confirmed the researcher that the activity of public relations today include in the public domain awareness, guidance and information in all areas of political and economic diplomacy accessible to the public have a benefit, and gain opinion of internal and external government policies.

The researcher said that the public relations today in the continent, the European use as a means of strengthening the unity of European .ookd on the number of countries, the European witnessed a special development of the concept of public relations to become a practitioner Tha of an international concept already practiced in relations Atah.autam the establishment of agencies, international public relations community and carry The responsibilities of international public relations and others as it is in the US Information Agency, to achieve the objectives of US policy, by explaining, interpreting and disseminating American policy and countering anti-propaganda directed against the states in the world. Then he touched on Talk about Egypt and how the State Information Service (SIS), the governmental body of the Egyptian Ministry of Information, acts as an official media and international public relations agency.

The researcher also stressed the importance of public relations among governments and civil society institutions when they face crises that threaten their ability to compete and continue to perform their functions. (Muhammad, 2013) 


\section{Title : Official diplomacy and multi-track diplomacy Researcher: Dr. Abdel Hakim Soliman Wadi \\ Date: 2013 \\ Summary}

The researcher began to talk about the development witnessed in international relations, where the diplomatic phenomenon has become the main entrance through which to achieve the policy of peace and war, and to achieve protection and care of the interests of States. The former tries to understand global politics and international relations as a whole, while the other focuses on explaining global politics and international relations. He has traditionally focused on understanding the behavior of the foreign policy of the state, governments, and those on behalf of those countries. Known as official diplomacy.

The official went on to say that, official diplomacy is no longer a secretive nature of foreign diplomacy. However, stressed that it needs multiple parties to achieve the objectives and priorities of foreign policy, so the researcher took the study.

A number of central questions have been asked, to what extent can we distinguish between official diplomacy and multi-track diplomacy, and how overlapping, intertwined, and complementary are official diplomacy and multi-track diplomacy?

He talked about the existence of two subjects used by the researcher to answer the questions of the study, the first diplomatic between the official and the parallel and the second diplomatic multi-tracks. Then he touched on some of the concepts that help study, such as foreign policy and others.

The researcher adopted a number of methods, such as the historical approach, where he focused on studying the historical developments witnessed by the concept of informal diplomacy. A descriptive approach to the study of the subject and attention to it and described it accurately. A functional approach that enables us to highlight the role of informal actors in the political decision-making in the field of international relations, and the methodological approach to show foreign policy as an open format for the internal and external environment.

The multi-track diplomacy has managed political relations among nations, as well as seeking to enhance the national interest of the country through understanding and influencing the outside public. (Abdel Hakim, 2013)

\section{Title : How to understand international relations}

\section{Author: Bahrain News Agency}

Year: 2012

Summary

It seemed $t$ article talking about the nature of the relationship between the old countries and was characterized by stability sometimes and other instability contrary, talk about the contacts that were made between the countries are international relations at that time, and also the permanent quest for States to establish relations with other countries through international relations Diplomacy and embassies, and then the subject of the existence of many factors that are affected and affect these relations was discussed, and it was also mentioned that the development of international relations emerged and developed, then the media developed and the national states were formed, and also when the wars that led to the establishment of relations with In order to reach peace and security solutions. The writer added that the most important characteristic of international relations is the lack of privacy and the retreat of the principle of non-interference in the internal affairs of States and this will be affected and affects relations all whether it is a party or were not. (Bahrain News, 2012).

\section{Title: PR is a way out of political crises in Egypt}

Author: Dr. Walid Khalaf Allah

Date: July 2012

Summary

The writer began his study by talking about the importance of public relations in the institutions in general and then mentioned the objectives of public relations in any institution, especially the institutions of the presidency, including gaining public confidence in the institution of the presidency, and maintain the reputation of the institution in front of its public and public opinion and society in general. How the institutions of the Egyptian presidency suffer from the inability to communicate with the public or with the rest of the organs of the state official and thus happen to flounder in decisions and attitudes. It was stated that because of the lack of a specialized public relations service, it could perform its duties fully and not be convinced of its existence 32

Lack of conviction by leaders and presidents of important public relations roles. Therefore, Khalafallah stressed that the structure of the public relations apparatus in the Egyptian presidency institution and the rest of the state institutions must be restructured. The writer made an appeal in his article to Egyptian President Mohamed Morsi. He stated that the institution of the presidency could only be completed with an effective public relations apparatus. One of the pillars and basic elements that help the institution of the presidency to the success of its mission.

He stressed that the public relations system is through specialists and studies of public trends measuring public opinion and evaluation, and then talked about the fact that public relations is a major pillar of economic 
institutions, and that the fourth pillar in addition to production, distribution and financing is not a luxury or propaganda, Is integral to the activity of the institution that seeks to gain public confidence and influence.

He cited examples such as the United States, where public relations have become an institution in their own right, and the European continent, which exploits public relations as a means of strengthening European unity.

Then seal his article by example of what our master Muhammad peace be upon him at the beginning of the Islamic call to inform him of the new religion and the conversion of the Koranic community of ignorance to a sophisticated society and change the mental image, although he does not have any media. (khalafallah, 2012)

11. Title: A proposed conception of the role of public relations in the networking of civil society institutions in the light of the concepts of strategic planning.

Author: Rahed Yosef Abu Jabra, nedaa khaddar mahana

Year: 2012

Summary

The researchers adopted dividing their research into three e chapters, the beginning of the framework and theoretical literature study and then in the second chapter study methodology, the last chapter has been to focus on data analysis and selection of hypotheses Aldrash.rkzata on the role of public relations in the networking between NGOs and the effectiveness of the public relations department in raising the level of Cooperation and participation among NGOs and the importance of developing a proposed concept based on the effective concepts of strategic planning. They started by talking about the public relations department and its importance and effectiveness in the institutions, duties and responsibilities of the public relations department, Of the Public Relations Department in Palestine, and stressed that public relations in Palestine were not exercised in its current sense until after the establishment of the Palestinian National Authority in 1993. They mentioned that the Public Relations and Media Relations Syndicate was established in Palestine on 22 February 1995, Jerusalem headed by Ahmed

Khalil Mohsen. On January 1, 1996, a sub-committee of the union was established in the Gaza Strip under the chair of Professor Nassar Abdel Hadi Nassar. The Public Relations Syndicate ceased to function as a trade union in the Gaza Strip in 1998.

They talked about the concept of public relations and networking and the term networking and its importance for public relations and civil society institutions civil and others. After they took the expansion of the development of public relations and public relations and strategic planning, elements of planning and steps and benefits of public relations activities and the media and some studies that emphasize the role Public relations as the primary propaganda of any successful institution.

In the end, the researchers reached a number of conclusions and recommendations, including that there is a belief among institutional staff that networking leads to improving the reputation of the institution and that public relations is the close friend of the public. It is necessary to raise public awareness about the concept of networking and the importance of public relations in institutions, and the marketing PR department should be promoting a special financial item in the annual budget when it is prepared. (Abu Jabara, 2012)

\section{Title : Public opinion, composition factors and methods of measurement}

\section{Author: Abdul Karim Ali Aldibsi}

Year: 2012

Summary

This talk about public opinion and the growing interest in the book, it ensures that public opinion is linked to all aspects of human life and society, that public opinion manifestation of collective behavior, and the strength of this public opinion force cannot be ignored in any society or any country. This book is divided into six chapters, including all of these chapters in order to talk about the emergence of public opinion and definitions and development, and the second chapter divisions of public opinion and types according to several specific criteria, the third chapter was a The fifth chapter dealt with the formation of public opinion, determinants, psychological, political, economic, social, religious and educational factors, and the role of public opinion and the patterns of behavior used by public opinion in the fourth chapter of the book. In the last chapter of the sixth, it was talking about two topics, the first methods of measuring public opinion and the second topic, public opinion polls and their importance and tools and steps. The book ended with a number of supplements to some of the surveys, which show the basic contents of public opinion polls and techniques and how to choose and determine the sample from the real living models. (Al - Dabisi, 2012)

\section{Title: Media and Crisis Management (BOOK) \\ Author: Abdul Razzaq Mohammed Al Dulaimi \\ Year: 2012}

Summary

The writer dealt here with the subject of media and crisis management at all times, even before the occurrence, when the emergence of indicators that are a warning of the possibility of a crisis at any time soon, the book contains eleven chapters, where the first chapter talked about the concept of communication and crises 
linguistically, Based on the principle that the management of any crisis is done through the existence of a modern communication system is true based on the full knowledge of the concept of communication and the latest stages reached, especially in terms of the development of the era of modern technology, and the writer through his book to some models that had a strong impact on The media.

The book touched on the media topic that is considered one of the most important means that should not be avoided when for any of the crisis, which must be wary of the media ignored, because ignored increases the tread of the severity of the crisis, and thus becomes a reverse attack from media companies and institutions in crisis what.

The author did not complete his research without clearly referring to the concept of the crisis, which is one of the matters of the present and future of the institution or the company in case it cannot be dealt with. The crisis is a need out of the ordinary or a situation that is very contrary to the strategy or objectives of the institution, a significant change in the existing strategic balance. It should be noted that the period in which the crisis takes place is a critical and unstable period and its characteristics occur suddenly.

It was to talk about ways and methods of E. absorption crisis and deal with them in a manner and verification methods less Ksai , and was the method of continuous talking to the media of the most important stages in the steps to deal with crises, and in order to avoid the occurrence of any rumors reduce the chance of good management of the crisis.

The writer's focus on a golden rule says: "When the news quickly, it stops the spread of rumors and rumors and calms the nerves in social circles, and with regard to the objectives of controlling the crisis, there is no complication in (AlDulaimi, 2012)

\section{Title: Public diplomacy becomes more attractive as the world becomes more open \\ Author: Dr \\ Date: December 2011 \\ Summary}

Began researcher his research certainly on factors several made public diplomacy more influential and one of the appropriate means in this age more publicity and public relations that were campaigns more influential in the past, what made many of the countries are looking for methods of new and more attractive and receptive to the peoples of other countries, and this has made Public diplomacy is on the surface to help official diplomacy achieve its goals.

Taking the researcher goes towards international changes that public diplomacy has given greater importance of an increase in the influence and impact of the global non - governmental, non-profit, and the increasing importance of public opinion and its ability to influence governments as becoming governments pay much attention to public opinion and the mobility of peoples that proved the power of influence in projection systems As in Tunisia, Libya and Egypt. He also talked about technology and its impact on peoples as well, either the second factor is globalization, which is one of the most important factors that increased the importance Public diplomacy The era of globalization, as the writer said, is an era of active and interactive governments that can create a good mental image that will help them win the trust of the peoples and civilizations of other nations. And also urges the impact of organizations is the profitability and increasing its influence on the diplomatic and other factors mentioned are the satellite channels and its direct impact on public opinion, and stressed that these factors used in his research make public diplomacy a DA of the task to gain the sympathy and understanding of the world 's foreign two policies and Mahlah.ozkr that the political leadership was the only player in determining the relations of countries to each other and to influence political decisions.

In the end, the writer talked about soft power, its influence and its ability to persuade and influence public opinion, which is of increasing importance to military or economic power. Therefore, from the writer's point of view, the establishment of a clear and public diplomatic policy is necessary to help communicate its ideas and views not only to governments but to peoples Also . (al-Awad, 2011)

15. Title: "The role of public relations in the diplomatic sector" An applied study on the offices of Arab and foreign embassies

Researcher: Dr. Walid Khalafallah Mohammed

Date:

Summary

The researcher began his thesis by mentioning the importance of the existence of public relations and international public relations in the world due to the technological, economic and political changes that have taken place. The study came in six chapters. The first is the methodological framework of the study from the problem of study and the importance of study and previous studies. He talked about diplomacy in terms of its definition, history and development and then go to compare diplomatic science with other and relate to science and at the end of this chapter spoke about the diplomatic activity under which institutional forms and a $\mathrm{n}$ diplomatic work has become linked to work with Limy .

Turning to the third chapter to talk about the media and diplomacy, he addressed the subject of international 
media and diplomacy and the concepts of international communication and its importance in the diplomatic field. He went on to media diplomacy and communication technology. At the end of the chapter, he presented the media flow and its impact on contemporary diplomacy and the reality of Arab media. Arab diplomatic systems The researcher concluded that the lack of control and lack of control from the poor countries are at risk of losing control of the fundamental aspects

Chapter IV dealt with international diplomacy and public relations, where the researcher believes that public relations has become an important part of the economic, political and social lifestyle of many people as a result of the complexity of interests and international goals, and then to the theories and the roles of contemporary international public relations at the end of the broad extent of the use of communication technology " and multimedia Modern " in the practice of international public relations in the diplomatic sector, and in the last two chapters talked about international public relations and international communication, the practical side of the study was this aspect is two modes I study Meade The second and the hypotheses of the field study, And then the results of the study and its recommendations and recommendations, and then the limits of the study and what it raises from future studies and section recommendations to categories, including recommendations for Arab and foreign embassies,

And to the exercise of public relations in the diplomatic sectors, diplomatic media and its use in the diplomatic sectors. (Khalaf Allah, 2010)

\section{Title : Palestinian Public Diplomacy after the Second Legislative Elections \\ Author: Dalal Baja's Mustafa Hammed \\ Date:2010 \\ Summary}

Hamid began the concept of public diplomacy and A are the global theories underlying, then the researcher moved to take some of the studies that meant Palestinian public diplomacy to end the development of salvation includes all aspects of the research to separate the first.

Then the researcher moved in the second quarter towards the Palestinian public diplomacy framing through shed light on what is the new public diplomacy and how to be a solution is for the Palestinians and its importance to the Palestinian issue and the relationship between them and the public opinion polls, and to start using public diplomacy with the Palestinians, especially indicators of Islamic yen, Where they stopped at the Palestinian public diplomacy between duty and reality, and the tools and dimensions required to activate them through daily communication strategic communications and development of long-term relations, And the best ways to use technology in the dissemination of Palestinian public diplomacy and the importance of unifying the programs of Palestinian non-governmental actors in the field of diplomacy and ultimately compared to Israeli public diplomacy .

The third chapter took the researcher to go towards the applied models of the Palestinian public diplomacy, the role of organizations and civil Palestinian inside and the Diaspora Palestinian public diplomacy with the support and by offering examples of prominent organizations or institutions of civil society actors in the dissemination of the Palestinian cause in various parts of the world. Stands after the remarks in the context of the experience and the role of the mass media to show these organizations and the increasing support for it, also touched on the public diplomacy role in activating the crucial issues of the Palestinian people over the past decade, such as the siege of the late President Yasser Arafat, and the advisory opinion of the Hague tribunal, and the siege of Gaza and the Goldstone report And the popular position on these issues. Then she finished Chapter set recommendations: including the establishment of the Institute for diplomatic training, the establishment of centers of public opinion poll external.

The appendix contains the most important questionnaires formulated by the researcher and used to monitor the reality of Palestinian public diplomacy among official circles, NGOs and the media, such as the Internet. The researcher known personalities that have been made with interviews during the period of preparation of the study. (Hammed, 2010)

\section{Title : Public diplomacy and its place in foreign policy}

Author: Philip M. Taylor

Year:2010

Summary

The researcher began the importance of public diplomacy in international relations, especially after the terrorist attacks that took place on September 11 in the cities of New York and Washington. Where he stressed that the formulation of public diplomacy is a dating back to the sixties of the last century has been used as an alternative to propaganda, it has tried to put this new term that does not Ivkro n word " the propaganda " or propaganda to link the term at the grassroots level of lies, Lying is not something negative is undesirable, but also not commensurate with the foundations of the moral upper any common democratic system in any form of forms International communication. But the mere fact that public diplomacy is a alternative phrase favorite does not automatically mean that they become mere words other used to avoid repeating the foul phrases at a time when 
both activities related to the other, but they do not order one but not identical, propaganda deliberate attempt is usually to make people behave or Itvkron the way they want and unwanted, which are primarily useful in the first of the source of diplomacy something different in spite of its proximity to the publicity, it works as M. Lin 's foreign policy through the creation of public acceptance in countries foreign to the activities of the State and other This is by highlighting the culture and national values and the dissemination of news and information, has been inches at many countries, the European official bodies and semi - official acting on behalf by the name of cultural diplomacy, Britain has the British Center, and the Germans have " Goethe Institute " and others work primarily the first to provide the training of languages foreign in countries The foreign press and the sending of the national exhibition or prominent speakers in foreign tours, the aim is one to inform the foreign audience to the best of what the mother country hasIt makes the public feel better about the state of origin, so as to promote mutual understanding among peoples and thus good relations between countries. Public diplomacy has focused on educational exchange and student exchange, because face-to-face interaction is a more effective way of influencing people and gaining their support. (Phillip, 2010)

\section{Title : phenomenon Corruption Political : Reasons And Effects And ways Processed : China Model Author : Dr. Ibtisam Mohammed Al Ameri Year :2010 \\ Summary}

The researcher began her study with an overview of corruption and manifestations of corruption. She said that corruption, regardless of its different levels and degree of gravity, has penetrated into every aspect of modern life like China and affects economic prosperity, political stability and social dynamism. People also think that this picture has a lot of corruption and reverse reality.

The researcher presented two sections based on the hypothesis of her first research, which included the theoretical framework of the concept of corruption, and the second included a model on which the research was based, the phenomenon of corruption in China after the process of modernization in 1978.

She stressed that corruption, which in our view is an illegal practice of public office, is a problem shared by the nations of the world, but these nations differ within themselves in terms of their understanding and perspective of corruption, in the circumstances of its inception, the motives of its spread, the extent of its penetration, the mechanisms of combating it and the danger of its spread. Then he explained the manifestations and forms of corruption according to the practiced, and some of the factors and causes the driving of corruption, comes the researcher to differentiate between the positive and negative corruption here influences touched positive effects, although many thought he was not there any positive effect but some countries happen with this effect, and finally in This chapter talked about ways to reduce corruption and its effects.

The researcher went on to give a model of corruption in countries such as China, where corruption in China is one of the most difficult problems faced by modernists, and touched on the history of corruption and its roots in China and then its forms and factors, causes and effects, whether negative or positive and ways to reduce it.

In the end, the researcher talked about two capacities for corruption, the first ability to reproduce itself when it offers the conditions and the appropriate environment, especially when the deterrents are weak and ineffective, and the ability to beat corruption practitioners at any time and place, especially in the absence of religious and moral detractors. (Al Ameri, 2010)

19. Title : Diplomatic and Political Media

Author: Dr. Amjad Al Hashemi

Date:2009

Summary

The book consists of five chapters, starting with the definition of politics in general and foreign policy in particular and different definitions over periods with some definitions of political thinkers. The author explained the nature of the relationship between diplomacy, media and foreign policy with the goal of each. After that he moved to look for the impact of the media in society and the extent of the impact of society's views of things that change in the balance of international powers and mentioned the importance of the role played by the media in the circulation of news and information must therefore be given attention to these means, and the writer mention the media theories of influence. In the third chapter we talk about political media, and based on the principle of bad image taken from the relationship of media policy comes here to emphasize the great role played by the media in the implementation of what you want and plans for policy and that came a look of ability Media access directly to the community and its members, was also talking about the political functions of the media with the explanation, the fourth chapter occurs in which the writer for diplomacy and the international community through the meaning of diplomacy to clarify and explain the change in which over time leading to diplomacy in the contemporary time now, said their characteristics and types, through the depth where access to mention the types and explained in detail, and through all that has been talked about in the previous chapters came Chapter V concludes explaining described globalization and the new world order and its impact on politics, diplomacy and media through the male definition and manifestations Ado $\mathrm{T}$ globalization and order 
Aljdid.oonhy researcher book talking about what should be characterized by the diplomacy of tomorrow as it builds dialogue among civilizations rather than conflict Among them , the establishment of a single world order and the rule of diplomacy of peace rather than violence, force and individualism. (Hashemi, 2009)

\section{Title: Public relations and overall quality management \\ Author: Shaaban Hamdi Mohammed}

Year : 2002

Summary

It urges the researcher on the fact that the concept of public relations in different organizations, and they have proven over the years as a profession able to respond to the needs of society have, a job worthwhile and optimized in order to carry the banner of change for any organization, and discussed the researcher said by the challenges that still face relations public, but despite those challenges remain for those who ultimately prevail is more organized and influential deeper and more able to achieve its objectives.

After that, the researcher through the orientation of numerous scientific studies in the field of public relations on the role that can be public relations management functions Ali plays a on the basis that this role ensures that public relations position desired is always a senior management level, and to emphasize that this role ensures Public relations ability and effectiveness in the face of future developments of contemporary institutions.

The researcher then began to explain the concept of TQM and pointed out that this concept is the strategic approach to produce the best product or service through continuous innovation. Then the researcher tackled the method of applying the TQM concept and linking the first step to public relations, is the first and aare a step for any successful business, and then explain how to activate the concept through public relations, and so out of the overall quality of public relations management agree in that they are targeting the basic goals of the organization and a $\mathrm{n}$ their integration with each other to achieve these goals more effectivelyand a ENA, The writer explained the role of public relations and security information in achieving the concept of total quality management, which is through the attention and communication with the masses of external and internal To create good reputation and excellent mental image. (hamdi, 2002)

\section{Title PR scenario}

Writer : Ali Hussein Mohammed

Date : 2000

\section{Summary}

Speaking writer in this book about the importance of public relations everywhere, and the importance of care of them and give them the value of direct administrative level with senior management, the author has to include considerations that stood behind the public relations and was the reason for the development that took a prominent place in our world, and a are four considerations Which focused on the writer, first the growing strength of public opinion, and the writer's opinion that public relations are affecting this force, which is taking charge of any organization or institution and through the directions and tendencies of this force, and the second is the revolution in the tools of communication means Quotations Data, It is this that has made the individual or individual from a local citizen to a global citizen compared to what he has at the highest levels of the world. Hence, public relations have an impact in this country as it is widespread and effective and has a great impact in the institutions of all other countries.

The third consideration was the emergence of giant organizations owned by the masses, and the writer means that, like other institutions and international organizations, modern and positive development also these organizations need such global organizations, and the role that brings them to the highest levels in the political, social and economic community is the Department of Public Relations, Finally, and most importantly, increasing the brunt of the attack on organizations with cash, and that means the occurrence problems and crises, note that the old did not have any interest to these criticisms, Alan, according to the first account and the growing public opinion force emerges over the impact of any It has a small or large enterprise or organization because of the growing power of public opinion and consistently high impact.

According to the author the importance of communication, and is considered as the most important tools , which has the effect and the most common and exposed to the eyes, and adds that he needs more who bear the general body of knowledge, ie comprehensive in everything knowledge surrounds the place where he works, a person of public relations and all that in order to ensure the work more realistically solve To the problems correctly and thus all this increases the trust in public relations, which is not at the required level of confidence now. (Ali Hussein, 2000)

21. Title : The role of public relations in facing crises and security disasters

Author: Muhamad Jamal al qadi

Date: 1998

Summary

The researcher deals with the definition of public relations in detail, and then began to talk about crises in 
general and then the allocation and clarification of the largest crises and security problems, and linked the work of public relations in terms of planning planning to resolve and confront security crises, which need a mechanism different from the mechanisms of resolving other crises.

The judge said the difference between the crisis and the disaster that through the good differentiation and the person can prepare well to cope with crises, and the researcher to clarify the terms and steps to prepare public relations plan in the face of security crises and disasters.

And he presented the judge in the research paper, a set of results of the study and was the most important of his call to focus on the bases used by public relations in resolving security crises which are being based on scientific grounds, and he is certainly the importance of understanding and applying the concept of "prediction" which has important Bdjaly security services in full readiness To confront any security crisis and thus reduce the percentage of losses that can be brought by these crises.

The recommendations, the researcher recommended the importance to the formulation of the line and strategies for public relations in the security field, based on theories predicting the security and expectation, and stressed the importance to include educational and training curricula of HR security on three important and significant meanings of terms a "security forecasting and research operations, and crisis management, And security disasters ".

The most important and best item is the establishment of crisis management in each security institution, because of the importance of the continuous work of public relations, which depends on the prediction through a permanent analysis of everything that is happening and know before that all the events and events that happen, and it is important to note the importance of practical training in dealing with crises Security through the use of false communication methods and false alarm, vigilance monitoring, security awareness and many methods that reduce and limit the occurrence of many security crises. (qadi, 1998)

\section{Title: Recent trends in public relations \\ Writer : Khamis Mohamed Abdel Moneim}

Date : 1970

Summary

Turning a researcher in the study to talk about the concept of public relations and emerging in which the functions and their functions and activities, and spoke of interest in public relations through mind important means of consolidating trust between them and citizens through the media within government agencies and administrative authorities, where the researcher noted in His research into trust, which is the basis of public relations, also said that the first concern of the thinking of studying public relations from the sides of the theoretical and practical is the subject of social responsibility and thus social progress, and spoke a researcher on international relations of the Organization and from the premise that work for $\mathrm{Z}$ public relations in which more complicated, especially if the organization of international relations also depends on the number of countries that deal with the organization, Thus, the position of International Public Relations Manager becomes so difficult that only competent men are chosen for their work. The researcher pointed out that the Director of International Public Relations addresses the use of a range of messages suited to changing social and political circumstances.

At the end of the research, the researcher said that since it is known that the means of public relations differ from one country to another, those who are based on these relations would change their methods depending on the local conditions they face in order to create the appropriate atmosphere for public opinion. (Moneim, 1970)

\section{Comment on previous studies:}

Previous offer of studies and research articles indicates increased more attention recently in the study of public relations in general, and attention to studying specific and ad hoc aspects, and this is what touched the work team through as confirmed by the results of previous studies of the role of public relations actor and fundamental in the political and diplomatic action, Which created the desire of the working group to expand on this and work on the excellence and detailed clarification of the work of public relations and the same factor in the diplomatic field.

The study has benefited from previous studies and research in the methodological aspects, problem identification and research tools. However, it differs from the above, which seeks to clarify and discriminate against the public relations work in the diplomatic corps in particular, and what distinguishes it from work in the field of public relations in general, not in the Palestinian Ministry of Foreign Affairs, which is a model for the title of the study.

\section{Research Methodology}

The research team adopted the descriptive analytical method, by providing an accurate description of the problem of research, and relied on previous studies, books and websites documented by the source.

3.1In addition, analytical descriptive approach: The descriptive method depends on the study of reality or phenomenon as it exists in reality and is done as a precise description and expresses a qualitative or quantitative 
expression. (Toukan, 1982, p. 183)

\subsection{Search Tool:}

Based on the interview as one of the most important methods of collecting information and monitoring the emotions and feelings of the person being interviewed, the research team relied on the simple observation form and personal interview as a tool to serve the research methodology.

"A conversation conducted by a person with another or with others; for the purpose of obtaining information in his search, they are direct contacts in which the person being sought and interviewed is face to face and is considered a conversation or two-way communication between them, in which the researcher directs questions to the respondent and receives his answers" Quality, 1997 p. 86).

\subsection{Community Search:}

Employees of the Palestinian Ministry of Foreign Affairs

\section{4_The research sample:}

The staff of the Palestinian Ministry of Foreign Affairs in the department is equally equal to the public relations department in other institutions.

In addition, Dr. Mamdouh Gabr, Senior Advisor in the Refugee and Expatriate Affairs Sector at the Palestinian Ministry of Foreign Affairs. Former Ambassador Dr. Ahmed Sobh, Director General of Yasser Arafat Foundation, former Deputy Foreign Minister and former Ambassador, Dr. Amjad Abu Ezz Lecturer, Political Science Department, The national specialty is international public relations.

\subsection{Method and procedures:}

The research team tried to make the results of his study comprehensive about everything related to the work of public relations in the diplomatic corps, and the team relied on the tool of the interview and direct observation simple, as the most appropriate tools to achieve the objectives of the study and answer its questions.

\subsection{Procedures for collecting information and studying}

The research team did the following for information about the study:

- The team searched first for the meanings of all the terms of the study title and related to it, via the internet and the library of An-Najah National University.

- The team took dates with figures who worked and are still working in the diplomatic corps and with a lecturer at An-Najah National University to specialize in international relations and public relations.

- A note form has been prepared and has been filled out as required.

- The team directed to the interviews on the dates identified.

- The team used written notes in all interviews, and voice recording was not used in one interview.

- Interviews were conducted within two weeks.

- The team emptied and analyzed the interviews and the observation form.

The following tables are a sample of interview questions and a note form:

\section{Table 1 Interview Questions Form}

\begin{tabular}{|c|c|c|c|c|}
\hline $\begin{array}{l}\text { Question } \\
\text { number }\end{array}$ & the question & $\begin{array}{l}\text { Answer the } \\
\text { first interview }\end{array}$ & $\begin{array}{l}\text { Answer the } \\
\text { second } \\
\text { interview }\end{array}$ & $\begin{array}{l}\text { Answer } \\
3\end{array}$ \\
\hline 1 & $\begin{array}{l}\text { What is the definition of public relations in the } \\
\text { diplomatic corps in particular }\end{array}$ & & & \\
\hline 2 & What do we mean by diplomatic information? & & & \\
\hline 3 & What is political communication and its methods? & & & \\
\hline 4 & $\begin{array}{l}\text { What are the characteristics of the diplomatic } \\
\text { personality and the person working in public } \\
\text { relations and the tasks entrusted to him? }\end{array}$ & & & \\
\hline 5 & What is political marketing and its importance? & & & \\
\hline 6 & What political crises and how to deal with them? & & & \\
\hline
\end{tabular}


Table 2 Observation form

$\underline{\text { Standards }}$

Use of websites

Use social networking sites information recipes

published

Type of published
information recipes

Section responsible for the dissemination of information and information materials
Indicators

$\underline{\text { Notes }}$

- The presence of a website for the ministry to publish news

- The presence of an embassy website to publish news

- Continuous updating of the website

- There is a check box for visitors to the site

- The existence of social communication sites of the Ministry

- The existence of social networking sites for embassies

- Continuous follow-up and direct response to comments and messages

1- Disseminate information continuously

2- Continuous dissemination of information about events and

events

3- Disseminate information accurately and explicitly

4- The information published is of interest to the Palestinian population or the outside population

1- Sections or units responsible for the dissemination of information

Sections responsible for preparing reports and information materials

\section{Finding and Discussion}

\subsection{View and analyze results for interviews:}

In order to ensure that the work of public relations in the diplomatic corps is consistent with the agreed content and scientific fundamentals, the interview questions, answers and comments will be presented and then compared to the contents and agreed scientific rules regarding public relations in the diplomatic corps.

\section{Table 3 Interview Questions and Answers}

\begin{tabular}{|c|c|c|}
\hline mber & the question & Analysis of answers \\
\hline 1 & $\begin{array}{l}\text { Definition of } \\
\text { public relations } \\
\text { in the } \\
\text { diplomatic } \\
\text { corps }\end{array}$ & $\begin{array}{l}\text { The results of the study are based on three }(3: 3) \text { responses. The same answer to } \\
\text { this question confirms that public relations in the foreign ministry do not } \\
\text { represent a special unit or department for a number of reasons, including that the } \\
\text { Ministry of Foreign Affairs considers itself to be the public relations of the whole } \\
\text { country, And that everyone who works it must be familiar with the work of } \\
\text { public relations recipes, and this confirms the importance of the public relations } \\
\text { of the State itself. }\end{array}$ \\
\hline 2 & $\begin{array}{l}\text { What is } \\
\text { diplomatic } \\
\text { media and its } \\
\text { functions? }\end{array}$ & $\begin{array}{l}\text { The three interviews with the competent authorities in the field of international } \\
\text { public relations emphasized the importance of the role played by the political } \\
\text { media and its proximity to the term political marketing, but there was an answer } \\
\text { to one of the interviews, }\end{array}$ \\
\hline 3 & $\begin{array}{l}\text { Communication } \\
\text { process and its } \\
\text { features in the } \\
\text { diplomatic } \\
\text { service }\end{array}$ & $\begin{array}{l}\text { The result of the study was unanimous that the State Department is a tool for } \\
\text { political communication, thus communication is one of the functions and basis of } \\
\text { international public relations. The answers support all specific characteristics that } \\
\text { must characterize the political communication process because of the sensitivity } \\
\text { of the issues dealt with by the State Department. }\end{array}$ \\
\hline 4 & $\begin{array}{l}\text { How } \\
\text { with } \\
\text { to deal } \\
\text { crises }\end{array}$ & $\begin{array}{l}\text { The results of the study showed that one of the three interviews in the sense of (1: } \\
3 \text { ) related to international public relations that there are no crises in the Ministry } \\
\text { of Foreign Affairs, as the diplomats are not policy makers, they are implementing } \\
\text { policy, the rest of the interviews confirmed that it cannot always be confirmed } \\
\text { That it will not get a crisis, and indicated the steps to deal with it in case it } \\
\text { occurred or in the event of a response to prevent the occurrence. }\end{array}$ \\
\hline
\end{tabular}




\begin{tabular}{|c|c|c|}
\hline the & the question & Analysis of answers \\
\hline 5 & $\begin{array}{l}\text { What are the } \\
\text { characteristics } \\
\text { of a person } \\
\text { working in the } \\
\text { public relations } \\
\text { of the } \\
\text { diplomatic } \\
\text { corps? }\end{array}$ & $\begin{array}{l}\text { The results of the study showed that there are certain characteristics that must be } \\
\text { given by the worker in the diplomatic field. } 100 \% \text { comes to the full and strong } \\
\text { perception of all the developments and the areas of the diplomatic country and } \\
\text { the country in which it is located. }\end{array}$ \\
\hline 6 & $\begin{array}{l}\text { Public relations } \\
\text { in the } \\
\text { diplomatic } \\
\text { corps and their } \\
\text { role in the } \\
\text { marketing } \\
\text { process }\end{array}$ & $\begin{array}{l}\text { The results showed that there is } 1: 3 \ldots \text { No. } 1 \text { is the ignorance of political } \\
\text { marketing and linking it to the media and political communication, and } 1: 3 \text { of } \\
\text { those who said that the concept is completely ignorant, and considered that the } \\
\text { successes obtained in gaining the views of other countries is a political } \\
\text { marketing, 1: } 3 \text { of the concept of the term and its importance and development at } \\
\text { this time, especially in the light of modern developments of the media and } \\
\text { modern communication. }\end{array}$ \\
\hline
\end{tabular}

\subsection{Discussion and analysis of the results of the interview:}

(Discussion of results in light of study questions)

First: the definition of public relations in the diplomatic corps in particular

By looking at the results of the answer to this question, the results of the study were based on three (3: 3 ) interviews with the same answer to this question that confirms that public relations in the Ministry of Foreign Affairs do not represent a special unit or section for a number of reasons, That the Ministry of Foreign Affairs considers itself to be the public relations of the whole State, and that all those who work must be familiar with the work of public relations recipes, and this confirms the importance of the public relations of the State itself.

Comes the answer in the negative to the presence of a specialized unit of public relations within the Palestinian Foreign Ministry as something positive as a whole and its divisions unprecedented public relations department for any organization ministry, confirmed the answers to that work, which is carried out in the Ministry of Foreign Affairs is the work of public relations of communication, and improve, reputation and good reception and implementation State policy, and that any work for employees within the ministry $\mathrm{j}$ considered public relations thus are the face of the ministry is working to coordinate with the Ministry of Foreign Affairs departments all .

These results, regardless of the lack of clarity of one decision is settled, but there is no dispute the importance of the existence of so-called public relations in the diplomatic corps, and its presence in the form of a full ministry similar to the large specialized public relations companies.

In light of the above findings, showing that the State Department is complete such as the Ministry and the members of all required of them work under the umbrella of the name and the concept of public relations, characterized by internationalism due to the nature of the Ministry 's work with other countries, and the lack of clarity in the precise and proper and comprehensive definition of the concept of international public relations.

Second: What is the diplomatic media and its functions?

The answers to this question show that the three interviews with the competent authorities in the field of international public relations emphasized the importance of the role played by the political media and its proximity to the term political marketing. However, there was an answer to one of the interviews, and therefore does not use it, but puts its name parallel to the name of the diplomatic media. On the other hand, that it is from that group that is considered political marketing is different and that as commercial marketing is the marketing of goods and the people are not sold and bought, so used the method of denial and denial of the existence of such a term.

The focus of one interview was that there are three functions and objectives of the political media: preparing press reports, promoting (marketing) the state, improving the image of the state and giving the impression of a beautiful face.

It has been shown that there is a great role for the media in influencing the diplomatic work, and it is able to use it in an excellent and planned manner that can achieve the desired objectives of the ministry as a whole and internationally as well, which benefit the relations with other countries in order to gain solidarity with him and provide assistance to him. Political media is a job to write reports and coordinate with journalists

In the light of the above results, it was found that there is a lack and a lack of proper and deep understanding of the political media in comparison with what has been seen in the references and previous studies. 


\section{Third: the process of communication and its advantages in the diplomatic service}

I have all the interviews involved that the Foreign Ministry is a tool for political communication, and that political communication has specific diplomatic channels in the ministry and recognized by the representative of the embassies or sending envoys or be directly oral and thus contact one of the functions and the basis of international public relations, and supports the answers to all specific qualities must Characterized by the process of political communication because of the sensitivity of the issues dealt with by the Ministry of Foreign Affairs, but in one interview was considered the Committee that is facing crises

Is the same that conducts the communications operations of the ministry and convenes every eight months, and the results showed that

The Ministry is a channel for political communication, through which the delivery and access to what the state wants, and other results that there are limits and determinants of the process of communication is characterized by a lack of haste and advertising only if the approval of the authority of the decisions and transparency and accuracy of any Minister of Foreign Affairs himself.

Building on previous results, it thought some in the State Department that the communication process occurs only in the event of crisis, and that the Special Committee to dissolve the crisis is responsible for the communication process, and this wrong belief, each task or function of a special section or special unit planning and implementation have, In order to ensure that results are obtained as required. In addition, that embassies and consulates are carrying the message and do not contribute actively to the process of political communication, as confirmed in one interview, the diplomat is a message holder and not the maker.

In the light of the above results, it was found that there is a lack of awareness and awareness of the tasks of each department regarding the media and its functions.

\section{Fourth: How to deal with political crises}

By answering the interview questions, the results of the study showed that one of the three interviews in the sense of (1:3) related to international public relations that there are no crises in the Ministry of Foreign Affairs as the diplomats are not policy makers, they are implementing a policy, (2:3) stressed that it cannot always be assured that there will be no crisis, and indicated the steps to deal with it in case it occurred or in the event of a response to prevent the occurrence, where the research team through the answers that the concept of the crisis is immediate, If the crisis occurs, this is something wrong, since it is especially in the diploma corps C. There must always be plans Lk I yeh renewed and continuous planning and modernization in order to avoid the occurrence of any crisis caused an imbalance in the balance of the ministry and therefore the balance of the entire state, as the State Department against the state.

In the light of the above results, the research team emphasizes the importance of having a unit of permanent and continuous planning in order to avoid any crisis, and to be able to cope with crises in the event that they occur in correct, scientific and systematic ways based on the availability of an excellent amount of information Facing the crisis.

Fifth: What are the characteristics of the person working in the public relations of the diplomatic corps? Through the above results show that everyone is $100 \%$ agreed on the importance of qualities must possess the diplomatic person, not the most important comprehensive knowledge of all that surrounds him from the news and information of all kinds and fields all either in his country or in the country 's envoy to represent his country in which as a diplomat or ambassador as being a bearer of the message and not the inventor of her, comes another recipe after knowledge is the ability to overcome the confusion factors of any attempt to disrupt the operation, and this requires a good ability of the diplomatic, especially endurance, they have confirmed all of them that the qualities of a diplomatic person are the qualities of a person PR is the first thing that is done Diplomatic training it is the skills must possess them, a training on public relations skills.

In light of the above findings, the research team emphasizes on the importance of the key factor in the diplomatic work which is the same person, he is the message holder and the owner of the mind and the bomber, who manages her.

\section{Sixth: Public relations in the diplomatic corps and their role in the marketing process}

The results showed the presence of 1: 3 .. Number 1 is the ignorance of political marketing and linking it to the media and political communication, and 1: 3 of those who said that he is not fully familiar with the term, and considered that the successes obtained in gaining the views and support of other countries is a political marketing, And the ratio of 1: 3 of the concept of the term and its importance and development at this time, especially in the light of modern developments of the media and modern communication.

On the other hand, for one of the interviews, it was her opinion that public relations are classified as a protocol and have nothing to do with external affairs. This is what the research team denies. Considered a public relations job.

In the light of the above results, the research team calls for working on defining the concept of political marketing and its employment in political work, and applying it effectively not only theoretically and intensifying the role of public relations in international institutions and not limited to the field of protocol only. 
Table 4 Analysis of the observation form

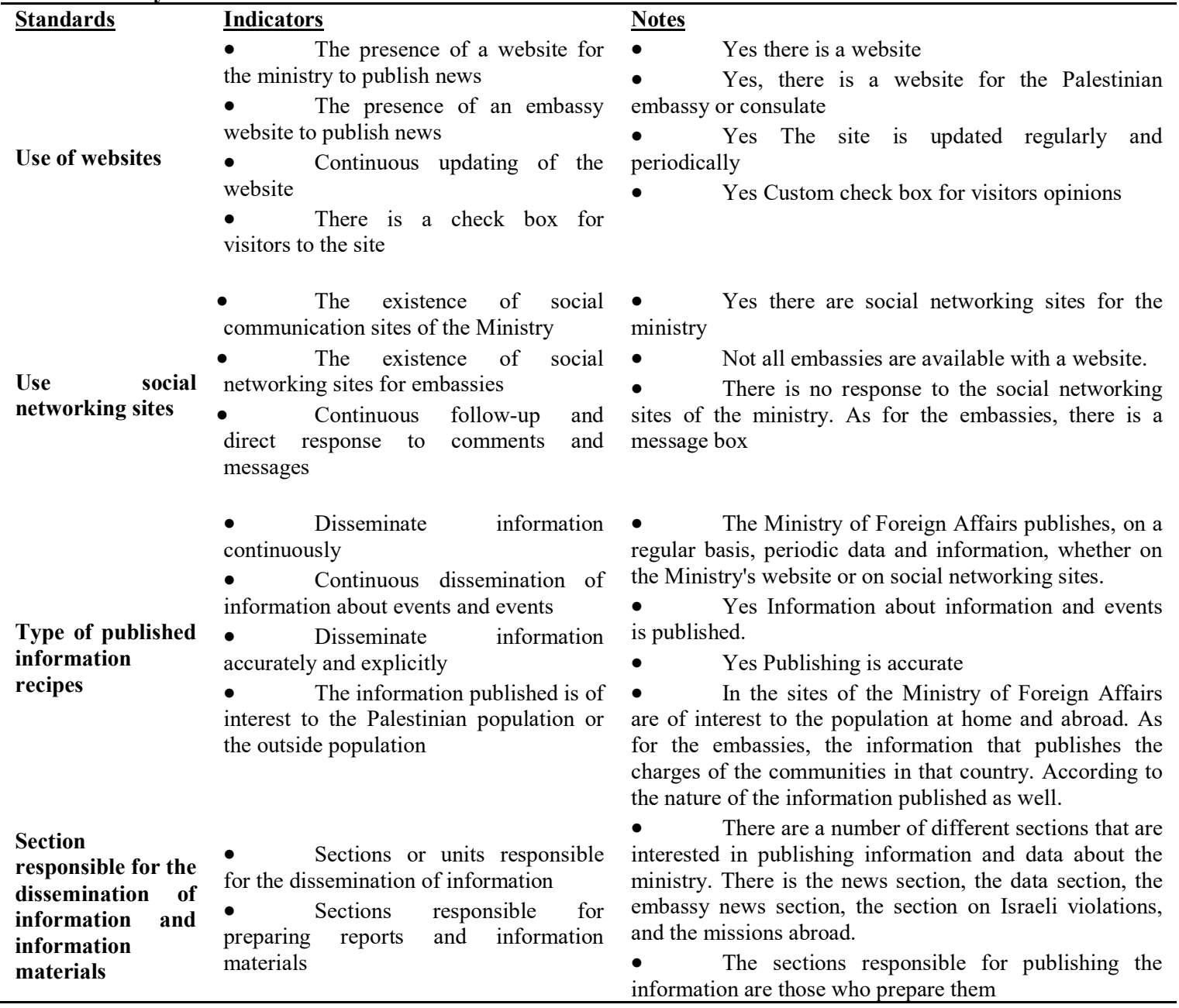

Analysis of the observation form:

Through the answers to the first block of the form on the use of websites, the Ministry of Foreign Affairs relies on these sites, and is characterized by talking constantly, and embassies also have their own sites, and with the most important feature is a box of views of those who enter the sites. In light of this, the research team believes that this aspect is very positive for the ministry, especially that it is not open to anyone who wants to communicate and visit the building to take information is allowed.

The social networking sites, The State Department contained the site's electronic ministry, and there are no replies in its pages, that of the work and mission of public relations, continuous and immediate communication of any inquiry or service, unlike embassies themselves, they are interacting on social networking sites, in the light of this the research team believes that you must use social networking sites to make it easier for them to read and study the needs of public opinion, especially in light of technological development, which is available to everyone Altobeiar his opinion through the means of these.

In terms of information disseminated, it is about events in the country of origin and in the country where Palestinian embassies are located. This information is accurate, as it affects information at the local and international levels of the State itself and the receiving State of the embassies. Events and events that occur, Journalist. In light of this, the research team felt that no matter how the ministry published news of credibility and transparency, the ministry must do work, campaigns and workshops to prove this, not through the publication of the news is verified.

As for the responsibility of publishing news and information materials, each section publishes news and events related to its section. In light of this, the research teams believe that when a single media unit is a public relations unit, the information collection and dissemination department manages several methods that make its readers fully and fully convinced of their credibility. On the other hand, each department carries out its fullScience and media, and requires the experience and look of people who have studied this as a large and large science. 


\section{Conclusion}

\section{Of the results:}

1. There is no complete public relations unit in the Palestinian Ministry of Foreign Affairs, but only a small section of the Protocol Unit in the Ministry has been formed because the Ministry of Foreign Affairs as a whole is considered one of the public relations tools of the State.

2. The concept of public relations in the Palestinian Ministry of Foreign Affairs is limited to reception, courteous and good-looking protocol.

3. There is no comprehensive and complete definition of public relations in the diplomatic corps.

4. There is a lack and a lack of proper understanding of political media compared to what has been done in previous studies.

5. The ministry exploits the media only to publish news, reports and data and does not use it in order to gain international support and gain world public opinion.

6. The Ministry of Foreign Affairs does not have a full unit specialized in permanent and continuous planning in order to avoid future or expected crises. The ministry is limited to a committee that convenes periodically every eight months. Its members are specific people, none of whom is a public relations specialist.

7. Lack of understanding of the concept of political marketing and therefore not used, as a modern term, knowing that it is an old term, but the new is currently the methods used to achieve the goals of political marketing.

8. The Ministry of Foreign Affairs recognizes the importance of public relations through training public relations skills.

9. The Ministry's use of the websites.

10. The ministry does not use social networking sites.

\section{Recommendations:}

1. The need to understand the full and correct concept of public relations and its functions and importance in the diplomatic corps.

2. The need to activate the role of social networking sites in the work of the ministry

3. The need to establish a full public relations department followed by protocol, protocol, media, planning, crisis and event units.

4. Need to work to understand and understand the concept of political marketing and work on the application of methods.

5. The need to intensify the activities of the Ministry in order to prove its proper role in improving the Palestinian reputation at the local and international levels. The ministry has concluded the positive image and gain the support and the permanent and ever-increasing support, thus creating and establishing a full public relations unit.

\section{References}

- Issa, H. (. (2016, 6 5). "Public Relations and Diplomacy. Retrieved from dunya alwattan: ". http://cutt.us/tCnX9

Abdel Hakim, W. (2013, 2 2). A Study entitled "Official Diplomacy and Multi-Track Diplomacy Urban Dialogue Issue: 4317, Department of Studies and Research. Retrieved from Rachel Corrie Palestinian Center for Human Rights and follow-up of international justice: http://rachelcenter.ps/news.php?action=view\&id=10894

Abu Jabara, R. (2012). , Muhanna A study entitled "A Proposed Concept for the Role of Public Relations in Networking Civil Society Organizations in the Light of the Concepts of Strategic Planning". Gaza: Islamic University of Gaza, Institute for Community Dev.

Adel, A. (2012, 3 3). "Political Marketing": An article published in the electronic newspaper. Retrieved from Donya Al Watan: http://cutt.us/ce3QU

Ahmed, B. M. (2007). "Methods of Scientific Research in the Sciences of Information and Communication. P. 7. Algeria: University Press.

Al - Baldawi, A. (2007, 4 2). "Managing crises .. Iraq model. Retrieved from http://cutt.us/T1Xj

Al - Dabisi, A. K. (2012). "Public opinion and factors of composition and methods of measurement.". Amman: Dar Al-Masirah for publication and distribution.

Al Ameri, I. M. (2010). phenomenon Corruption Political : Reasons And Effects And ways Processed : China Model. baghdad: Kufa Journal of Legal Sciences.

Al-Anzi, A. R. (2016). "Political Marketing Theory: Concepts and Implications in the Political Field,p 57. Gaza: Al-Azhar University.

al-Awad, T. (2011). Public diplomacy becomes more attractive as the world becomes more open. The Diplomatic Magazine - Saudi Arabia, , Issue 58, pp. 26-29. 
AlDulaimi, M. A. (2012). Media and Crisis Management. Amman: Dar Al Masirah for Publishing and Distribution.

Al-Hashawi, M. (2012, 4 2). "The concept of marketing and its importance": An article published in the site of economy for all. Alexandria. Retrieved from "The concept of marketing and its importance": An article published in the site of economy for all. Alexandria

Ali Hussein, M. (2000). Public Relations Scenario" Volume 13, Issue 1, pp. 43-74. Department - Egypt, , pp. 43 74.

Bahrain News, A. (2012, 4 4). How to understand international relations. Retrieved from https://www.bna.bh/

Beauty, R. A. (2005). Political Marketing and Media: Political Reform in Egypt. Egypt: The Egyptian Lebanese House, pp. 20-23.

Behind Allah, W. (2012, 3 2). "The International Public Relations Industry in Contemporary International Relations. Retrieved from " website of the Arab Organization for Public Relations and Popular Diplomacy: http://cutt.us/vqSNw

Ben Mersley, A. (2007 ). "Methods of Scientific Research in the Sciences of Information and Communication": University PresP. 8. Algeria. : University Press.

Ben Mersley, A. (2007 , 3 2). "Methods of Scientific Research in the Sciences of Information and Communication": University Press, Algeria. P. 8. . Retrieved from http://cutt.us/VnkZZ

Casinav, H. (2014). "Political Communication: Models of Political Communication". Journal of Human and Social Sciences, University of Algiers.

Dulaimi, A. R. (n.d.).

Hakim, W. A. (2014, 4 5). The Role of Informal Diplomacy in the Implementation of Palestinian Foreign Policy. Retrieved from Dunia A1 Watan Newspaper.: https://pulpit.alwatanvoice.com/content/print/334372.html

hamdi, m. s. (2002). Research entitled "Public relations and management of overall security quality". Journal of Security and Law - Dubai, Volume 10, No. 2, pp. 180-220.

Hammed, D. B. (2010). - Hamid Dalal, A Study entitled "Palestinian Public Diplomacy after the Second Legislative Elections. Rammallah: Graduate School, Birzeit University.

Hashemi, A. A. (2009). Diplomatic and Political Media. Jordan: Dar Osama for Publishing and Distribution.

issa, h. (2014, 3 3). International Relations and Diplomacy. Retrieved from dunya alwattan: ://cutt.us/YvkPL

Issa, H. (206, 6 5). "Diplomatic Character and its Features". Retrieved from dunya alwattan: http://cutt.us/qPtsv

Khalaf Allah, W. (2010, 5 4). "The Role of Public Relations in the Diplomatic Sector: An Empirical Study on the Offices of Arab and Foreign Embassies" Cairo. Retrieved from An Empirical Study on the Offices of Arab and Foreign Embassies" Cairo: http://cutt.us/t9vY

khalafallah, w. (2012, 4 2). "International Public Relations in Contemporary International Relations. Retrieved from website of the Arab Organization for Nation Relations and People's Diplomacy: https://www.madvix.com/EG/Giza

Mersley, A. (2007). "Methods of Scientific Research in the Sciences of Information and Communication. Algeria: University Press.

Mersley, A. B. (2007). Methods of Scientific Research in the Sciences of Information and Communication". Algeria: University Press.

Moneim, K. M. (1970). Research entitled "Modern trends in public relations. Department - Egypt, Volume 2, No. 4, , pp. 71-76.

Muhammad, A.-B. (2013, 2 1). a study entitled "Multi-track diplomacy. Retrieved from , Rachel Corrie Palestinian Center for Human Rights and follow-up of international justice: http://rachelcenter.ps/news.php?action=view\&id=10894

Phillip, T. (2010). Research entitled "Public diplomacy and its place in foreign policy, Issue 52, pp 38-41. Saudi Arabia,: Diplomatic Magazine - Saudi Arabia.

Prince, N. (2013, 4 3). "Reflections on Political Media": The Intellectual Newspaper. Retrieved from . http://cutt.us/dOYke

qadi, M. J. (1998). the Role of Public Relations in Confronting Crises and Security Disasters. Third Annual Conference on Disaster and Crisis Management - Egypt, Volume 3, pp. 258-275.

Saleh, S. (2015). Media and Public Diplomacy. Amman: Dar Al Fikr Publishing and Distribution.

Tarawneh, A. (2009, 5 4). "PR Century Industry". Retrieved from http://cutt.us/VYfbW

Tim Dunn, M. K. (2016). "Theories of International Relations Specialization and Diversity" . aman : dar dejlah.

Wadi, A. K. (2013, 4 2). "Official diplomacy and multi-track diplomacy. Retrieved from " http: // cutt. us / $\mathrm{Rj} 0 \mathrm{Lb}$

Youssef, H. (2016). Political Media. amman: dar dejla.

\section{Interviews}

First interview: Dr. Mamdouh Gabr Senior advisor in the refugee sector and expatriate affairs in the Palestinian 
Ministry of Foreign Affairs

The second interview: Dr. Ahmed Sobh, Director General of Yasser Arafat Foundation, former undersecretary of the Palestinian Foreign Ministry and former ambassador

Third interview: Dr. Amjad Abu Ezz Lecturer in the Department of Political Science at An-Najah National University.

\section{The observation form questioner \\ 3. Appendix \\ 1. Notice form questioner \\ 2. Interview with Dr. Mamdouh Gabr \\ 3. Interview with Dr. Ahmed Sobh \\ 4. Interview with Dr. Amjad Abu Ezz}

Appendix (1)

Table 1 form Note questioner:

Research Title: The nature of the work of public relations in the diplomatic corps "The Palestinian Ministry of Foreign Affairs as a Model"

Date of Observation: From 1-2-2017 until 30-3-2017

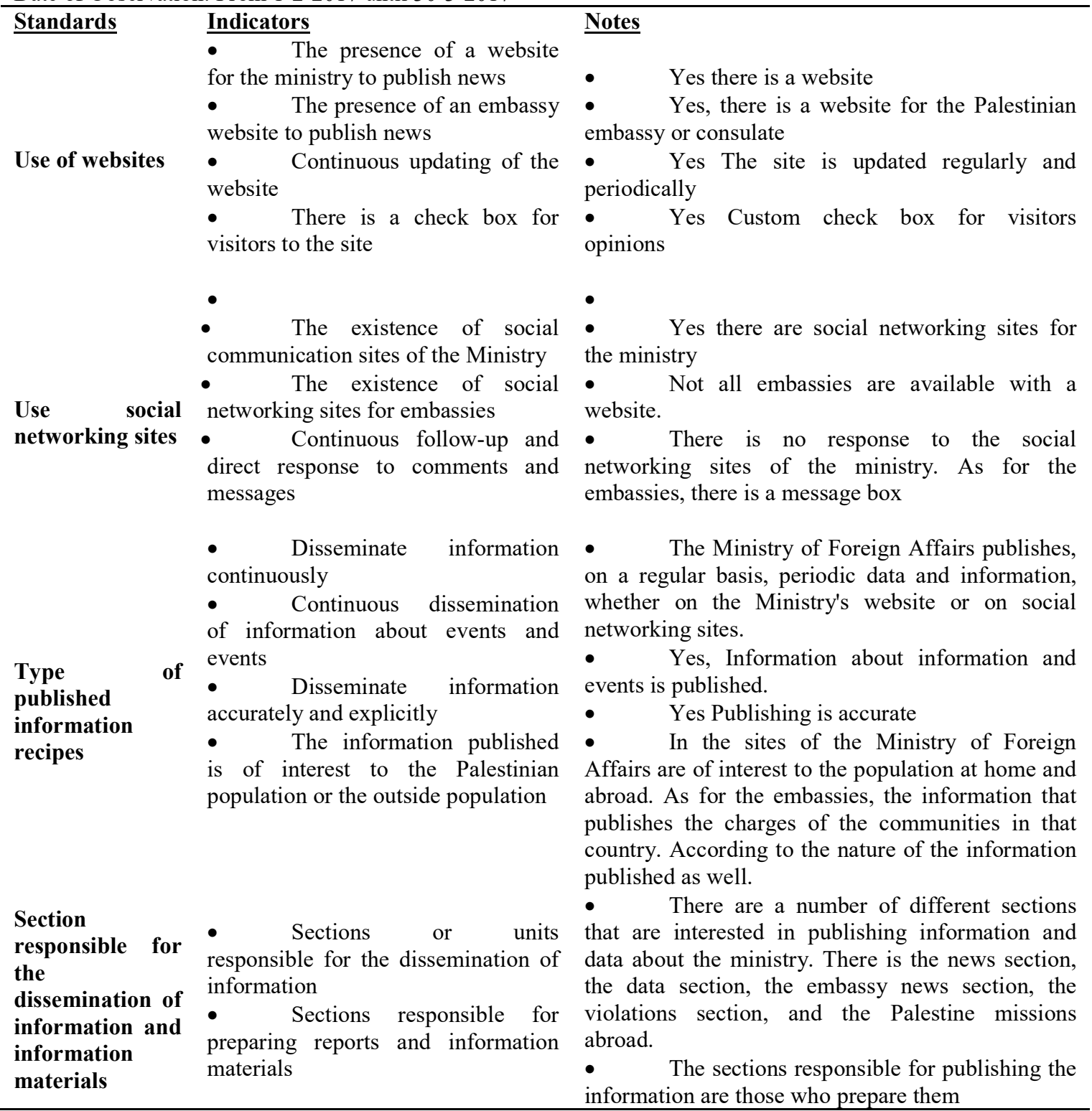


Appendix (2)

Interview with: Dr. Mamdouh Gabr Senior Advisor to the Refugee and Expatriate Sector at the Palestinian Ministry of Foreign Affairs and former Ambassador to Palestine in Switzerland

Q 1: What is the definition of public relations in the diplomatic corps?

First, the smallest employee in the Ministry of Foreign Affairs to the highest employee is a public relations man, there is no person and a public relations specialist in the Ministry of Foreign Affairs, and we do not employ or take any person specialized public relations. Preferred in the Ministry and give priority to those who study political science and economy and then who holds a certificate of specialization the public relations department or the public relations unit is not an independent department in the ministry. A simple department is supposed to be affiliated to the general administration of the protocol in the case of communication between us in the ministry and embassies residing in host countries. The public relations department is one of the most important departments in attracting and planning for the target in a sense, it is not permissible to give the status of a person responsible for public relations of the state and has psychological diseases that affect the external relations and affect the image of the ministry negatively

Q2: What is diplomatic media and its functions?

The media is a political term that cannot be issued any sentence without the consent of the same minister because it is sensitive and spread throughout the globe, who takes this position is a specialist in the media and are not entitled to publish anything or any information except after the personal approval of the Minister, The media is a political kitchen.

Q3: The process of communication and its features in the diplomatic service?

A leadership committee in the ministry that is in the process of communication and crisis solving if there are crises facing the corps carries out the political communication in the ministry. Every eight months there is a meeting or so-called operations room or emergency and the emergency committee is convened in case of a sudden event.

Political communication in the event of crises is formed by the crisis and to any party that follows the crisis and accordingly the formation of the emergency committee. Here the media has no role at all until after the study of the crisis and see the aspects so as not to publish anything that threatens the policy of the country and the state

Q4: How to deal with political crises?.

That nature and the body responsible for them resolve every crisis in the ministry, for example, if the body responsible for Asia suffered from the crisis of the department and management of that party is the one who resolves the crisis and not a public relations department in the ministry. Everyone is responsible for solving the problems of his administration through experts in management.

Q5: What are the characteristics of the person working in the public relations of the diplomatic corps?

Political marketing is not the best, but we got the recognition of the state 123 until 2017 on more than 123 countries recognized the State of Palestine is marketing to our Palestinian cause.

In addition, turned us from a terrorist organization in the eyes of all, especially the Arab countries 1965 to the Palestinian Authority and the State of Palestine.

Public relations, as we have said, are part of the protocol and have nothing to do with foreign affairs. It is true that it has an effective influence in the ministry and its role is important, but everyone in the ministry is a public relations person from the youngest employee to the biggest.

Q6: Public relations in the diplomatic corps and their role in the marketing process?

Diplomatic Personal Personal flexible open - educated and conscious of the desired event to be achieved, for example, I cannot go to a country to represent my country without the country 's geography and policy knowledge, whether government or opposition, we diplomats must be our relations are very open to a desirable goal, the diplomatic holder message is not the inventor of the message It must be successful in delivering the message, that is to say, it must control all the jamming factors that you encounter during the transmission of the message.

\footnotetext{
Appendix (3)

Interview with: Dr. Ahmed Sobh, Director General of Yasser Arafat Foundation, former Undersecretary of the Palestinian Ministry of Foreign Affairs

Q 1: What do you known public relations in the diplomatic corps?

Today the current diplomatic work has become a diplomatic her more than the face and more of some kind in the past diplomacy was limited to political representation in the sense Amir Sultan, head of state sends diplomatic envoy to the State of another particular political continues to certain political relations. But with the information revolution and with the enormous change in international relations by means of communication and means of transport has become a diplomatic less secret and political and more complexity and multiplicity, but it has become a commercial in a political and cultural nature of diplomatic relations and ecological character,
} 
and thus became Diplomat not only son selves or that which belongs to the upper classes, which holds the highest degree of Allen, but in the former sector or certification has become Sami employee must to have certain skills to convey the interests of his country to the State other and deal with it and thus become a kind of diplomat compelled primarily to Be a public relations person in the sense that he has the ability to communicate with others to convince them of common interests and to achieve the greatest possible interests of his country and therefore he may be a normal citizen. For example, I met diplomats from Arab countries who were diplomats Confined to a very small layer of society, but Alan has become a diplomatic available to all by the skills and the result of the study by the need. If the definition of public relations in the current diplomacy is no different from public relations in the local, sense skills study the ability to communicate intelligent marketing method of persuasion ability and provide an appropriate environment that is called win to win which means win. It does not mean I win at the expense of others and therefore diplomacy today became not only the head of state or the Minister of Foreign Affairs. There are types of diplomacy, including diplomatic parliamentary, for example, parliaments you, public diplomacy, public diplomacy are closer public relations of any and there is that civil society is based diplomacy organizations, civil work of a diplomat abroad in terms of communication with the other become countries produce their governments and foreign policy and diplomacy big named diplomatic Public diplomacy, public orientation is not for governments of civil society. The United States comes to Palestine is not only to talk with the official side, but also with the community and vice versa " and we are supposed to do public relations Tousle to unions student unions men universities inform public diplomacy of short say public relations in contemporary diplomacy is a process that continues to convince carried out diplomatic skills have those skills But his field of work abroad and not his community but in other societies."

Here you emphasize the importance of public relations in the diplomatic service such as the Ministry of Foreign Affairs, for example, there is no ministry but a diplomat who does not have the ability to be public relations is not diplomatic in the sense of today if I ask a Palestinian diplomat very briefly. This is an understanding, but this understanding is limited.

Therefore, we will make a distinction between the two fields to be clear what this section provides about that. Of course, the diplomat must be enjoyed the skills of public relations and develop diplomatic capabilities other if he did not have the ability to become a man and a centrist is capable of communication cannot be a diplomatic then skills public relations are necessary to build upon the skills of additional to become a diplomat, not necessarily to be a Palestinian foreign ministry department named public relations as All they do in foreign affairs is public relations, that's what I mean. However, during diplomatic training you start with public relations skills. Good listening to others. Know what you have to market to others. Know your strengths And therefore during the training process that is subject to the diplomat begins to train on the skills of public primary developed by the Etiquette Protocol of the knowledge of international relations, international law, diplomatic relations between the establishment of a consular embassy, the personality of the workers. What is the difference between the diplomatic ranks the difference between the diplomatic and consular all skills must be added to the skills of the initial public relations when he becomes a young man or a young diplomat.

\section{Q2: What is diplomatic media and its functions?}

There is no word Media diplomat There is the media must be marketed politically, the media must be credible and perseverance and pluralism there are ways and continues so diplomacies, especially in the Palestinian case , part of a fundamental of his work is to convey the media what is happening on the land of Palestine in the state , which is staffed by the media is exercised Is a transfer by means appropriate to the reality of his country in this case the importance of the national rights of the Palestinian people and here this diplomatic media changed previously, that is 30,40 years ago was the Palestinian media abroad is a media Palestine offers victims only, today we offer Palestine as a victim occupation also offer the face of another who is the face capable of institution - building creativity personal and collective Palestinians Palestinian collective ability to create and configure an independent in which a Palestinian modern state of all modern state components and thus the media diplomat who detoxified is to convey the reality of media Of foreign communities.

In foreign media different course is required from the media or the Department of Information or the Department of flags Foreign Ministry in general and foreign Palestine, especially the movement of official Palestine attitudes towards what is happening on the ground and all that has to do with us and leap statement enjoy accurate expression and delivery of diplomatic messages often assume the position of a political a which is not just to say " the occupation of the Israeli today confiscated 200 denims in the country Doe in favor of more settlements but we say that the difference here, for example, a man media For example in the Ministry of what says this talk and says a continuation of the policy of occupation. Foreign imposed that says this is contrary to international law and international law, humanitarian and contradicts explicitly Council resolution security 23.34 issued and contradicts pledges by Israel in international forums and agreements, the message must be to be in the original one but even cantered diplomatically even mobility diplomatically there are conditions preliminary to the news media That is, it should not be long, and it is supposed to be a summary that is supposed 
to be condensed and is intended to contain a position, not a transfer of what happened .

Q3: The process of communication and its features in the diplomatic service?

Political communication has specific channels, is recognized through the channels of foreign ministries, and is sent or opened embassies, missions, send envoys, or letters and all these means of political communication is recognized in the manner of its performance. While public relations is mainly communication and communication and communication diplomatic work communication and not necessarily notification no. There is a political touch declaring the whole because it loses its importance so it is subject to different rules and different forms, while public relations is communication and publicity.

\section{Q4: How to deal with political crises?}

There are no crises in the diplomatic corps, diplomats are not policy makers, and they are policy enforcers. Crises occur at headquarters rather than diplomatic embassies do not suffer from the crisis, governments are suffering from a crisis because it is here represented by means if our ambassador in a country or our embassy , for example, this country 's relationship with us is no longer as it was or weakened or cooled happens has a crisis but it is a crisis in the relationship as a whole, primarily Diplomatic crises are caused by relations between States, not by the diplomat himself and by the diplomat by his calm performance

Q5: What are the characteristics of the person working in the public relations of the diplomatic corps?

Today the standards have changed. I do not see any of our young people. He has no ability to be a diplomatic personality. The most important advantage of a diplomat is to be full of love and knowledge of his country. If he does not know his country and is not convinced of what his country means, he cannot be a successful diplomat because he is essentially an ambassador abroad. What is the degree of any diplomat to any country in the world? The first condition is appropriate knowledge of the conditions of his country from its customs and cultural traditions, secondly to be in line with the skills required now, for example someone who knows nothing about international relations and the world's geography and world politics The most important what is happening around him, thirdly the skills of other communication skills public relations media languages, languages are important not necessarily to have had many languages but at least to have a language of international $\mathrm{m} \mathrm{Aarav}$ between everyone, who hears the translation cannot be up to the mainstream of society the other becomes He sees the translator's mouth and the translator's eyes. addition To all this must be known more about the country that goes by there are many countries around the world are working for a diplomat before going for the site and to carry out the conditions that take place between the two countries, a full - sized bilateral relations between the two countries.

Q6: Public relations in the diplomatic corps and their role in the marketing process?

Palestinian diplomacy in the seventies and eighties of the last century was marketing (her speech) was limited to the political side, which was full of resistance to the policies of the occupation by calling for international solidarity with us, has been introduced new elements of this marketing media discourse, for example our discourse is looking for relations of direct benefit to the Palestinian people In addition to the above, for example, building schools, social assistance, health, culture, infrastructure, our marketing discourse needs the greatest possible benefit to the Palestinian people, through its settlement, the realization of this relationship to what is in the interest of today is a tool Measurement and therefore speech is not speech itself any goal is not meant at first speech was the goal of the former was the political discourse goal in itself because it conveys the suffering conveys a message Alan This is necessary but not sufficient must be added to the benefit of the Palestinian people and only became a speech boring bias not Take one.

Appendix (4)

Interview with: Amjad Abu El-Ezz, Doctor of International Relations, An-Najah National University Q 1: What do you know about public relations in the diplomatic corps?

Always at any embassy in the world or in the Ministry of Foreign Affairs there is a thing called public relations, its work in general protocol, reception of guests and writing news and work in coordination with the press, and give the minister summaries about guests coming to the state or the state in which they are delegations, press summaries sent to journalists, this is that public relations is the point of the external ministry, which works to coordinate with the Ministry of Foreign Affairs departments all .

Q2: What is diplomatic media and its functions?

There is a diplomatic media tasks aimed at three of things, namely the promotion of the state represented by the embassy and be by working to improve the image and give a beautiful face from the state through the deal and the completion of what to do protocol, and the preparation of media reports about what is happening in delegate the state and the second goal, a defense, Ie work to defend any issue affecting the State represented by the Embassy, and representation in the diplomatic service, the third objective which is through the preparation of press reports on a permanent basis to the State to which it is represented and the State represented by the Embassy, E of public relations, a wider range of media and public relations

Q3: The process of communication and its features in the diplomatic service? 
In the diplomatic work every word calculated, so it must be a communication based on the accurate description of information and explicit and transparent, the information and transfer properly because any of the word incorrectly quoted as possible to harm diplomatic relations, and have significant impacts media report brief and clear without any error

Q4: How to deal with political crises?

Crisis management requires a plan to respond to crises and statements written and calculated, and not to increase the severity of crises, but reduce them through a counter-media plan to correct any particular line, and the media plan in cooperation with journalists launched an advertising campaign to overcome the crisis and correct any error, PR is the executive arm of diplomacy and the arm that promotes any state-related issue, maintains interests, and reflects the internal image of the state in which it operates and the state it represents.

Q5: What are the characteristics of the person working in the public relations of the diplomatic corps?

First, he must be patient, responsible, moral, religious and cultural. He must have a general, aware and politically aware culture so that he can represent his country, and is good at politics, political skill and national belonging.

Q6: Public relations in the diplomatic corps and their role in the marketing process? He re-spoke about the process of communication and information 